\title{
MIRAGE OF LUXURY? FALKE-GROUP POTTERY FROM THE BORDERLAND OF SILESIA, LUSATIA, BRANDENBURG AND GREATER POLAND
}

\author{
SŁAWOMIR KAŁAGATE - ARKADIUSZ MICHALAK
}

\begin{abstract}
Late medieval highly decorated Falke-Group stoneware, produces most likely in Lusatia, have been considered by scholars as a luxury product. More than a hundred fragment have been found in today's territory of Lubuskie voivodship, which in the turn of Late Middle Ages and Early Modern period was the borderland between Silesia, Lusatia, Brandenburg and Greater Poland. The analysis of the pieces from this area point to production in several different workshops, manufacturing also earthenware imitations. The context of analysed fragments indicate that they were used not only by aristocracy, nobility and clergy, but also aspiring burghers and possibly richer inhabitants of rural areas.
\end{abstract}

Key words: Falke-Group - medieval - stoneware - pottery - imitations - borderland - Lusatia - Silesia Brandenburg - Greater Poland.

\section{Zdání luxusu? Keramika Falkeho skupiny z pomezí Slezska, Lužice, Braniborska a Velkopolska}

\begin{abstract}
Abstrakt: Pozdně středověká, bohatě zdobená kamenina Falkeho skupiny, vyráběná pravděpodobně v Lužici, je badateli obecně považována za luxusní zboži. Vice než sto fragmentù této specifické skupiny nádob bylo nalezeno na územi dnešního Lubušského vojvodství, které na přelomu pozdního středověku a raného novověku tvořilo pohraniční oblast mezi Slezskem, Lužicí, Braniborskem a Velkopolskem. Analýza nálezů z této oblasti poukazuje na jejich výrobu v několika různých dílnách, vyrábějících rovněž jejich keramické napodobeniny. Kontext analyzovaných fragmentů naznačuje, že byla použivána nejen ve šlechtickém a církevním prostředi, ale znali ji také zámožni měštané a případně bohatši obyvatelé venkova.
\end{abstract}

Klíčová slova: Falkeho skupina - středověk-kamenina - keramika-imitace - pomezi - Lužice - Slezsko Braniborsko - Velkopolsko.

\section{Introduction}

In the late Middle Ages, tableware - an important element of the ritual of feasting and culture of the table practiced by the social elites of this time - became diversified. Not only was the set of forms richer, but also the raw material changed. In addition to the previously dominant clay and wooden products, expensive glass and tin vessels (Piekalski-Wachowski 2013, 144), and later also stoneware were introduced. As a predominantly imported luxury product, stoneware quickly gained a status of wealth (Schwarzberg 2012; Wachowski 2013, 135). It became a highly desirable product among the aspiring lower strata of society. The pursuit of status led to the adoption of new materials of production, providing the same functions as the old but less expensive.

This process can be observed with the example of stoneware vessels decorated with a characteristic, checkerboard pattern, called in specialist literature the Falke-Group (after the name of the German researcher who first extensively studied the problem of these products - Falke 1907). The main decorative motif consists of various arrangements of little square stamps with four dots (Nawrolski 1989, 467). Less common is the decoration with systems of five dots or crosses in the squares. The stamps are arranged in, multiple horizontal rows, large triangles, or cover the entire surface of the vessels. The motifs of opposing triangles, made of small convex triangles, or bands of small rectangles dotted with knurls, can also be found on this type of the vessel. There are also bands of small rectangles imprinted with a knurl.

In most cases, the bases are frilled. The vessels of this group are often ornamented with decorative masks: usually bearded men, less often women or young men. The characteristic feature of this group is a gray color of the body, mainly in a dark shade, with the outer surface covered in various shades of brown engobes and salt glaze. The group includes of the unusual, 
seemingly emblematic, form of beakers (in the shape of a shoed foot, hedgehog chalice, cylindrical, bag-shaped vessels with funnel necks, but also jugs or inversely conical vessels; Gaimster 1997, 282-284). On the basis of characteristic ornamental motifs, O. Falke erroneously defined the place of production as the village Dreihausen near Marburg in Upper Hesse (Falke 1907, 305-306). For many years, the products were called ceramics or stoneware of the Dreihausen type, despite the fact that there were voices criticizing such attribution (Horschik 1971, 30). The increase in finds from Central and Eastern Germany, with an evident concentration of discoveries in Saxony and Lusatia, prompted researchers to locate the places of its production, first in Saxony or Thuringia (Horschik 1971,30), and later in the Lusatian workshops, perhaps in Bautzen (Rode 2000) or Zittau (Stephan 2004, 294, 298).

The sumptuous decoration of the vessels with the use of motifs known from Gothic architecture, frequent polychrome, engraved ferrules made of copper-alloys, often with talismanic protective sentences and apotropaic masks of bearded men, led researchers to conclude that they were exclusively used by elites.

The occurrence of vessels of this group in monasteries, cathedral treasuries and churches as sacred vessels could have been the effect of their luxurious nature, or their attributed healing effects. According to Siklósi (1983, 159-164), this could be confirmed by an inscription on the silver fitting of the Trier goblet made around 1600, stating that the vessel was made in 1413 in Malta from St. Paul/?/ (Siklósi 1983, 159). The cup with the head of a hermit, appearing in 1467 in the inventory of the Duke of Burgundy, Philip the Good, allows him to indicate the relationship between the ceramics of the Falke-Group and the mythical clay of St. Paul, also known as Maltese clay, healing clay or terra sigillata (Siklósi 1983, 164-165). Medicinal properties, effective against heart failure and poisons, were attributed both to this raw material in the Middle Ages and in the early modern period, and possibly to liquids drank from vessels made of Maltese clay (Doležel 1998, 60). According to his hypothesis, the bearded faces from the vessels of Falke-Group should be associated with the image of St. Paul (Falke 1907, 302; Siklósi 1983, 164-165; skeptical Horschik 1971, 16; Holl 1990, footnote 19).

Evidence of usage of ceramic products of this group in very distant cities of Europe, such as Szczecin, Gdańsk, Brugge, Bergen, Tallinn or Dorpat representing the Hanseatic League, may prove that the burghers treated them as luxury goods (Dąbal 2009, 225; cf. Berry 1994, 8-13).

German scholars dated the appearance of vessels of this group to the first half of the 15th century (Falke 1907, 305). This was later confirmed by archaeological evidence obtained from regions/sites distant from Lusatia (Holl 1990, 215; Stephan 2004, 297). However, the possibility of their 14th century chronology (which was also allowed by O. Falke 1907, 305) cannot be ruled out; it is supported by the discovery from Greifswald in Mecklenburg, dated to the second half of the 14th century (Ansorge 2002, 255). However, this kind of ceramics is noticeably more common in assemblages of younger dating (from the second half of the 15th and 16th centuries). Their presence could be explained by a longer usage than in the case of traditional vessels due to their artistry and quality of workmanship. From the first half of the 15th century (early chronology) there are vessels found only in the Czech castles of Landštejn and Vízmburk (Břicháček 1997, 91; Sedláčková 2018, 221). The vast majority of the remaining finds are generally dated to the 15 th-16th centuries. This is due to the fact that these are often loose finds, without a stratigraphic context, obtained, for example, during the Polish Archaeological Record (further as PAR).

Within the territory of today's Poland, the ceramics of the Falke-Group are found mainly in towns and castles of the western regions of the country: Lower Silesia (recently Stephan 2004, 318, 324; Mackiewicz 2012, 137-139, Fig. 3; Glinkowska-Orawiec 2016, 222-223; Szajt 2019), Western Pomerania (Kamiński et al. 2009, 349, Fig. 11:1; Wojciechowska 2017; Słowiński 2020), Greater Poland (Pawlak 2007, 160, Fig. 74:8; Kowalczyk 2012, 196, Fig. 5; 2014, 37-38), and less frequently in Pomerelia (Dąbal 2009; Starski 2009, 228, Fig. 37:4; Nawrolska 2011). An impressive collection was also found in the borderland of Silesia, Greater Poland, Brandenburg and Lusatia, which covers the present-day borders of the Lubuskie Voivodeship. Until now, approximately 
100 fragments have been sourced from several locations; however, during a museum search, it was possible to identify another dozen fragments from sites of a various nature. Only 11 fragments from this area were physiochemically analysed (Schwedt et al. 2003, 236-237, 239-241), which confirmed their attribution with the Falke-Group; the place of production of remaining fragments was determined on the basis of formal features and analogies. In this paper, we would like to present a complete categorization of the discovered sherds, pointing to the elements that broaden the current interpretation and context of the finds, not only in a Polish but also European perspective.

\section{Technology of manufacturing}

Most of the pottery sherds in question come from the exquisitely made vessels. All of them were made of well-prepared clay and formed on a high-speed potter's wheel. The firing of the vessels in the most cases was performed properly. The granular fractions contained in the clay were melted, and only a few fractions have recorded the presence of unmelted admixture grains. The exception here is a fragment of the lower part of a cylindrical beaker from Żagan, where a significant amount of admixture was observed, causing a slight roughness of the vessel surface (Fig. 8:7). The colors of the body were usually gray or light gray, and less frequently gray with an olive shade, or brown gray.

In most cases, the analysed fragments come from those vessels covered with brown, dark brown, or brown with a cherry shade engobe, and then glazed with salt glaze. There have been exceptions to this rule. A few fragments are covered with engobe only, such as the bottom of a cylindrical beaker from Witków (Fig. 6:12). In the case of a few sherds, a different method of external surface finishing was observed. As a result of the firing process, they had strongly sintered, brown surfaces (in various shades). Some of them were unglazed, e.g. a fragment of the belly of hitherto unknown form from Stare Czaple (Fig. 3:8). However, most of them were covered with salt glaze, e.g. the lid from Witków (Fig. 5:10), or a fragment of rim from pear-shaped goblet coming from the same site (Fig. 6:7).

With one exception, engobe and enamel were placed only on the outer side of the vessels. Engobing and glazing on both sides were observed only on the jug from Przewóz (Fig. 3:6).

The preliminary technological analysis allows to notice that collected set of sherds is not homogeneous. It is highly probable that the analyzed fragments were manufactured in different pottery workshops. However, it cannot be ruled out that such differences occur within the products from one pottery center, but at the present stage of research, gathered arguments support the first thesis. What's more, the analysis carried out so far on the discussed material, seems to confirm it. Eleven fragments of both stoneware and its imitations from the area in question (from Witków, Zielona Góra and Żary) were analysed by the team of A. Schwedt (et al. 2003, 236-237, 239-241) by means of measuring its chemical composition. The scholars assumed that the specific trace elements present in the raw material used for the production of the pottery could be helpful in establishing their provenance. By using statistical methods for the analysis of the sherds, researchers identified groups characterized by a similar composition of the raw material, recognizing among them the compositions typical for the Falke-Group, Zittau, Muskau and Bautzen. The research showed that most of the tested fragments bearing the characteristic checkerboard pattern were made of clay characteristic for products of workshops manufacturing the Falke-Group vessels (Fig. 5:2, 9, 11-12, 6-10-11, 7:2, 17), with low concentration spreads, especially in elements $C e, E u, R b, S c$ and Th with a spread of less than $4 \%$ (Schwedt et al. 2003, 241). The fragment from Żary, which has unique form of ornament (Fig. 8:11), also belongs to this group. Interestingly, the chemical composition of the fragment from Zielona Góra (Fig. 8:1) clearly differed from the other tested fragments (Schwedt et al. 2003, 241). Another sherd discovered in Witków, significantly different in the technology of production and the decoration can be considered an imitation (Fig. 4:13); it was also made of ceramic mass with different composition 
(Schwedt et al. 2003, 241). However, it seems that there is a significant lack of a larger number of analyses to statistically substantiate the obtained results. Moreover, the comparative base from neighboring areas is undoubtedly insufficient to compare it with the collected data. From our perspective it is difficult to consider these results as significant.

\section{Vessels forms}

Among the discussed material, several forms of vessels are represented: cylindrical beakers, pearshaped goblets, lids, jugs and vessels of unknown (unrecognized?) form.

Most of the analyzed fragments were parts of cylindrical beakers. These include 58 fragments from: Międzyrzecz (4 fragments), Sulechów (1 fragment), Szprotawa (4 fragments), Witków (43 fragments), Żagań (4 fragments) and Żary (1 fragment). However, it cannot be ruled out that some of them were from pear-shaped goblets.

Among the fragments identified as parts of cylindrical beakers, 6 sherds were elements of the upper parts, 17 of body fragments, 22 fragments came from lower parts and 12 fragments from bases. The fragments from Żary (Fig. 8:11) and Sulechów (Fig. 3:9) are the best preserved among the upper parts of discussed vessels. Both come from containers, with rims of $8 \mathrm{~cm}$ in diameter, slightly tilted outwards, with a gray fracture and covered with a dark brown engobe and salt glaze. They are almost identically decorated, their bodies covered with single, square stamps with a raised cross in the interior. Only the zone where the body passes into the rim is ornamented differently. In the specimen from Sulechów there is a line made with a rotary knurl, limited on both sides by a delicately engraved groove, while the specimen from Żary is covered with horizontally engraved grooves and a plastic strip decorated with ribs. It can be assumed with a high degree of probability that both vessels were made in the same pottery workshop.

The remaining fragments of the upper parts of cylindrical beakers excavated in Szprotawa (Fig. 4:1) and Witków (Fig. 6:1,4-5), represent very similar forms. They have a high, undecorated neck, straight or slightly tilted. Its transition into the body is emphasized by a plastic rib, often notched, sometimes accompanied by a horizontally carved groove, underneath there are decorations with a single square stamp. Their rims are between 7 and $8 \mathrm{~cm}$ in diameter. Most of the lower parts of the cylindrical beakers are decorated with horizontally engraved grooves, with bands of vertical or slightly diagonal narrow bars made with a knurl. Above these bands appears an ornament typical of Falke type stoneware - little square stamps with four dots within, most often in the arrangement of opposing triangles. Such fragments have been found in Szprotawa (Fig. 4:4-5), Witków (Fig. 4:10; 6:13-15, 17, 19-21; 7:1-3, 27) and Żagań (Fig. 8:4-7). Unique are two fragments from Witków: with diamonds made of short, imprinted sections above the horizontal grooves and two bands of punctures (Figs. 6:16, 7:10). All bases of cylindrical beakers have a characteristic, wave-shaped pedestal. They were excavated in Międzyrzecz (Fig. 3:1, 3), Witków (Fig. 6:8-12) and Szprotawa (Fig. 4:2). Their diameters range from 9 to $10 \mathrm{~cm}$. Only their bottom parts are decorated. In the case of specimens from Witków, some of the bases may also come from pear-shaped goblets.

Cylindrical beakers appear quite commonly in the Falke-Group stoneware. In most cases, they have survived in the form of larger or smaller fragments. Complete forms are known from Dresden (Mechelk 1970, 106, Fig. 37:4, Pl. 31), the collection of the cathedral treasure in Limburg, Kunstgewerbemuseum in Berlin (Nawrolski 1989, 502, Fig. 2, 3), Krosno (Wachowski 2013, Fig. XII:a), Leipzig (Stephan 2004, 301, Fig. 13), Olomouc (Drnovský 2017, Fig. 5:1-2), Göttingen (Rode 2000, Fig. 1), and Wrocław (Stephan 2004, 319, Fig. 37).

The frequency of pear-shaped goblets, i.e. small vessels with the highest located width, is relatively high in the discussed materials. Twenty five larger or smaller fragments were assigned to this category, coming from: Chełmica (1 fragment), Sękowice (1 fragment), Witków (22 fragments) and Zielona Góra (1 fragment). Most of them, preserved in the largest fragments, were obtained during the study of the castle in Witków. In the material from this site, 2 larger sherds 
from the upper parts, 2 smaller ones and 4 fragments of the rims were recorded (Fig. 6:2-3, 6-7). The latter, by shape, position and finish resemble analogous parts of the cylindrical beakers. Separating them and assigning a specific category is often intuitive. Noteworthy is a large fragment of the upper part of the richly decorated goblet with a vertical rim. The transition of the rim to the belly is underlined by a notched rib; beneath it are three strands of single square stamps with four dots in the interior. There is a band of opposing triangular stamps with convex triangles below them (Fig. 5:1). The next large fragment of the middle part of the vessel comes most likely from a similar form of a goblet. Thanks to the plastic ribs with cuts and punctures, it has an angular profile. The decoration covers its entire surface, and between the ribs there is a band of triangular stamps with convex triangles in the opposite arrangement. Square stamps with four dots are imprinted below and above the plastic ribs, with no clear pattern (Fig. 5:2). The remaining sherds included in this category are small elements of bellies, most often decorated with a square stamp with four dots. Such were found in Chełmica (Fig. 2:1), Sękowice (Fig. 3:7), Witków (Fig. 5:2; 7:5-8, 11) and Zielona Góra (Fig. 8:1). The ornament of triangular stamps with convex triangles was recorded on the belly fragments from Witków (Fig. 5:3-7). All discussed fragments of the upper parts of goblets from Witków come most likely from different vessels. Similar forms of Falke type stoneware are known from the monastery of St. Peter in Erfurt (Stephan 2004, 298, Fig. 11) and Grodzka Street in Jelenia Góra (Skibiński 1999, 211-212).

The jug category includes 15 fragments from Krosno Odrzańskie (3 fragments), Luboszów (3 fragments), Międzyrzecz ( 3 fragments), Przewóz (4 fragments), Zielona Góra (1 fragment) and Żary (1 fragment). The best-preserved specimen was unearthed during the excavations in the moat in Przewóz. Its upper part has been reconstructed from 4 fragments. It is characterized by a cylindrical neck and a globular belly. The neck is decorated with three horizontal strands of equal-armed crosses impressed as a single stamp. They are separated from the edge of the rim by a horizontal groove, and from the belly by a plastic rib and two horizontally engraved grooves. The upper part of the belly is covered with single, square stamps with raised cross in the interior, forming a system of hanging triangles (Fig. 3:6). Fragments belonging to two vessels were excavated in Luboszów. The first is the lower part of a small, bulbous jug, reconstructed from two fragments. It had a separate base with a pedestal and partially obliterated cutting off marks. The underbelly is covered with single stamps with a cross within and forming a hanging triangle pattern (Fig. 2:9-10). The second vessel is represented by a fragment of the neck. It is decorated with a classic stamp with four dots, separated by a horizontal band of vertical oblongs impressed with a knurl (Fig. 2:8). Another, larger fragment of the bellied jug was found during the excavations in Zielona Góra. It has a separate base with a pedestal. The lower part of its belly is decorated with single, square stamps with four dots, creating a disturbed arrangement of hanging triangles /?/ (Fig. 8:2). The only handle in the analysed collection comes from the castle in Krosno Odrzańskie. It is a small fragment of the band with slightly thickened edges. It is densely decorated with typical stamp, delimited by ribbon of punctures on its edges (Fig. 2:6). The remaining fragments of jugs are larger or smaller fragments of the bellies. They are all decorated with single, typical Falke-Group stamp, forming an arrangement of rhombuses and triangles. They were recorded in the materials from Krosno Odrzańskie (Fig. 2:3-4), Międzyrzecz (Fig. 3:2) and Żary (Fig. 8:12).

Most of the stoneware jugs of the Falke-Group are stocky, with a rather high, slightly profiled neck and a band-shaped handle. Such specimens have been excavated in Bautzen (Stephan 2004, 307, Fig. 21), Guben (Rode 2001, Fig. 9), Cottbus (Rode 2001, Fig. 14-15), and Wrocław (Stephan 2004, 320-223, Figs. 38-39). The occurance of jugs is typical primarily for the region of Lusatia and Silesia, although this kind of specimens has been also found in Greater Poland (Stephan 2004, Fig. 44). Some of the discussed specimens come most likely from vessels of different sizes than the mentioned above. The greatest width of their bellies is located much lower. This feature is also noticeable in the jug from Kożuchów, discussed in the paragraph concerning imitations of the Falke-Group. The jug from Przewóz seems to be an exception (the shape of the upper part is very similar to the specimen from Wrocław). 
The so-called recessed lid excavated in Witków, reconstructed from 4 fragments, is undoubtedly a unique form in Europe. It is richly decorated and carefully manufactured. The handle is shaped in a form of a stylized flower with the delicately engraved petals around it; in the center of each petal is a round stamp with 7 grain size bumps. The edge of the lid is decorated with an ornamental band made with a hand knurling tool (Fig. 5:10). It shows similarity to the imitating petal flower base of the Frankfurt am Main pear-shaped goblet (Mackiewicz 2008, Fig. 7). The only other surviving lid, included in this group of stoneware, is at the Daun goblet. It is also a specimen of the so-called recessed type, topped with a handle in the form of a bearded man's bust (Falke 1907, 302).

The category of undefined vessels includes all fragments that we were unable to assign to a specific form. Most often this was the result of poor conservation or too much fragmentation. They are fragments of bellies decorated with square stamps from Krosno Odrzańskie (Fig. 2:5), Przewóz, site 22 (Fig. 3:5), Stare Czaple (Fig. 3:8), Szprotawa (Fig. 4:3), Witków (Fig. 4:9, 11-13; 7:21), and Żagań (Fig. 8:8-10). This group includes 3 pieces of molded face masks (?). They have been excavated in Międzyrzecz (Fig. 3:4), Witków (Fig. 5:11) and Żagań (Fig. 8:3). It is difficult to clearly determine what vessel they come from. All known forms of stoneware vessels of the Falke-Group were decorated with decorative applications. Judging from the profile of a fragment from Międzyrzecz, we can assume with a high degree of probability that it decorated the upper part of the jug.

Two fragments, probably from one vessel excavated in Witków, are also worth mentioning. The first is triangular in profile (Fig. 5:13), the second in the form of two vertical, closely spaced ribs (Fig. 5:14). With a high degree of probability, these fragments can be considered part of the elongated, narrow tips from goblet in the form of the pointed shoe (Trippenpokal), known from finds in the monastery of St. Peter in Erfurt and the Commandery of the Knights Hospitallers in Szekesfehervar (Barthel 1968; Siklósi 1983); dated to the first half of the 15th century. A fragment of another vessel of this form was discovered in the city of Zwickau in a barrel pit in Magazinstraße; however, without the characteristic stamped decoration (Beutmann 2002). One of the analysed fragments was probably the side part of the shoe tip, where it meets the wooden sole of the patten (Fig. 5:14), and another, due to its profile, can be considered an element of the wooden sole of the patten, adjacent from the underside to the elongated shoe tip. This is hypothetical interpretation because of the fragmentation of artefacts; however, very likely.

At the end we need to look at a fragment of uncertain type of vessel, excavated in Witków. It has a cylindrical neck decorated with horizontal grooves and a band imprinted with a knurl. The preserved part of the belly is decorated with a row of vertical dashes, under which there are single, square stamps with four dots within, forming most likely triangles (Fig. 5:12). The shape of this fragment resembles the upper part of a bottle, flask, a form so far unknown in the Falke-Group products. Against this thesis stands the fact that such vessels appear in the first half of the 16th century. It cannot be ruled out that we are dealing with a hitherto unknown form of a jug with a narrow, cylindrical neck, or, less likely, with a fragment of a jug with a tubular spout or unknown imitation of glass chalice. The question concerning the form of this vessel is still open.

\section{Decoration}

The most typical pattern appearing on the ceramics of the Falke-Group from the area in question is a square or diamond-shaped stamp with four symmetrically placed dots in the interior. It appears in at least 57 fragments analyzed in this paper.

A stamp in the form of a concave quadrilateral with a convex cross inside, was used to decorate fragments of vessels from Luboszów, Przewóz and Żary (Fig. 2:9-10, 3:6, 8:11). The vessels discovered in Poland were also decorated with this ornament, and are known from Poznań in Greater Poland (Kowalczyk 2012, 196, Fig. 5:1) and Szczecin, ul. Czwartkowa 8/9 in Western 
Pomerania; the later from the 15th-16th centuries latrine (Słowiński 2020). It also appears on fragments from the city of Görlitz in Upper Lusatia (Rode 2000, Cat. 24, Fig. 11:6), and the Vízmburk stronghold from the first half of the 15th century (Sedláčková 2018, 219, Fig. 7:4). Small single stamp in form of the cross appears on the rim of the jug from Przewóz (Fig. 3:6), but also on the imitation discovered during the research in Witków (Fig. 4:12). A similar ornament can be found on a fragment of a ceramic goblet from the Luleč Castle in Moravia from the first quarter of the 15th century (Doležel 1998, 53, 55, Fig. 2).

A unique, previously unnoticed form of decoration is represented by two fragments from Witków, i.e. the ornament of adjoining squares, filled alternately with convex horizontal and vertical lines (Figs. 6:16, 7:10). A single find also seems to be a sherd with a rhomboid stamp with a single raised dot in the center (Fig. 5:9).

A fragment of red earthenware decorated with a row of triangles, discovered in the Krosno Odrzańskie castle, finds its close analogies in the sherds discovered in the small town of Doubravník in Moravia, the Falkenštejn castle in North Bohemia and Branč in Slovakia, which can be dated based on coexisting materials to the 15th-16th centuries (Doležel 1998, 56-57, Fig. 9; Gabriel 1987, 48, Fig. 3).

An ornament in the form of circular stamps with a single convex point, is noticeable on only one sherd from Witków (Fig. 5:8). Fragments with similar decoration are known from Poznań (Kowalczyk 2012, 195-196, Fig. 5:7), Wleń castle or the chalice from Zaitz in Saxony-Anhalt (Rode 1999, Fig. 25, 32). This form of ornamentation seems to imitate decoration known from glassware (Doležel 1998, Fig. 5-6).

The fragment from Międzyrzecz is also unique in terms of the applied stamp ornament. It has a form of an imprint of a concave square field intersected by raised lines forming diamonds, with a single convex point (Fig. 3:4). Such motif was only recorded on a stoneware fragment excavated in the Dominican monastery in Tallinn (Russow 2014, Fig. 8).

The most interesting decorative motif appearing on the vessels of this group are the molded facemasks applications, which can be interpreted as apotropaic elements, protecting the owner from evil powers (cf. Michalak 2020, 19-20). Their presence was recorded on at least four forms (from Kożuchów, Międzyrzecz, Witków and Żagań); the jug from Kożuchów was decorated with two circular appliques. All of them differ significantly in terms of facial features, hairstyles and headgear. The Kożuchów facemask showing a half-profile face with a short, trimmed beard (Fig. 2:1), definitely different from the classic Bartmankrugs from Daun, Dresden, Bautzen, Kościan, etc., does not find its close analogy among the previously known vessels, although it seems they most closely refer to the image from the 15th-century jug from Bautzen and Göttingen (Rode 2000, Fig. 1; 2001, Fig. 15). A chubby face with an ornament of repeated circles at the bottom from the vessel of Witków (Fig. 5:11) finds its analogy in the 15th-century Zeitz chalice, where the mask of this form appear on the body and the foot of the vessel (Rode 1999, Fig. 25). The fragment with the image of a face with long hair, obtained in Żagań (Fig. 8:3), seems to refer to the vessel from Upper Lusatia (Rode 1999, Fig. 32). The application from Międzyrzecz fragment (Fig. 3:4) has no analogies in the available comparative material.

\section{Imitations}

Rapid development of the middle classes of late medieval society, during the second half of the 13th century and in 14th century, resulted in a large demand for imported goods, previously available only to a limited group of nobles (Hasse 1979, 7-10, 58-60). These products became an important indicator of the importance and social position of their users. This quickly emanated in the appearance of imitations of these inaccessible and rarely imported items in the local material culture, but produced with commonly available materials, especially from ceramics and wood. At the same time, imitations were both a cheap replacement for expensive originals and satisfied 
the desire for increased demand for expensive, aesthetically impressive, imported products. These tendencies also underpinned the appearance of imitations of the luxurious stoneware of the Falke-Group, made by local ceramic workshops. There are at least a few fragments of traditional products from the area in question, made both of ferruginous clays, which, as a result of firing in a strongly oxidizing atmosphere has given red color to the body, and of kaolinite clays with light, white or white-yellowish colors of the bodies.

The most impressive of them is a well-preserved jug from Kożuchów, excavated during the research on a burgher plot. It was obtained from a latrine fill (Fig. 4), built in the light of dendrochronological studies after 1474/1475 (Wawrzyniak 2012, 153, 156, Fig. 18). It is decorated with bands of triangles and squares made of an imprinted, four-sided stamps and covered with green lead glaze. The rim, top and base of the neck are decorated with a notched strip, mimicking most likely the rope pattern. The form of this jug refers to the specimen discovered in Guben, covered with an analogous lead glaze (Rode 2001, 11, Fig. 9). A fragment of an analogous jug covered with green glaze was also discovered during excavations at 4 Katedralna Street in Wrocław (Mackiewicz 2012, 147, Fig. 9:c). At the base of the neck, the vessel from Kożuchów is decorated with three circular medallions - molded applications with images of a bearded man, a young man, and a bird, which can be interpreted as an image of a pelican tearing the breast and feeding the young /?/ (Fig. 2:2). This motif, symbolically associated with the sacrifice of Christ, occurs, among others, on the cover of the lid, discovered in Ostrów Tumski in Wrocław, and probably coming from the Bolesławiec pottery workshop (Mackiewicz 2012, 145, Fig. 7:a). We also know examples of such decorations from Dresden (Horschik 1978, 437, 486). Both artefacts, however, date back to the 18th century. Interestingly, in 2007, fragments of Falke-type vessels were discovered in Bolesławiec, in a waste pit of one of the five modern Bolesławiec potters (Krabath 2012, 298-299). At the moment, it is difficult to say unequivocally whether they come from vessels made there, or accidentally got into the pit later, during numerous investment works carried out in the 19th and 20th centuries. Among the fragments obtained at that time, an unglazed overlay with the image of a young man was also discovered, identical to the one from the Kożuchów jug (Glinkowska et al. 2012, 136, Fig. 123-124). Also, some of the sherds with a light gray color of the body and brown glaze (e.g. fragments of Luboszów stoneware decorated with a single, square stamp with a cross in the interior) clearly refer to products from Bolesławiec. Ultimately, the problem may be resolved by future physico-chemical analysis of these fragments.

During the research of the burgher parcel at Łukasiewicza Street in Sulechów, together with fragment of the stoneware beaker discussed above, a second fragment was excavated, decorated with a typical stamp, but made of kaolinite clay and glazed with salt glaze (Fig. 3:10). It comes most likely from a cylindrical beaker or a small mug. It was excavated from strata dated before 1557 (Dziedzic 2009, 129, Fig. 3, 5). Interestingly, another fragment of an almost identical vessel, similarly decorated and glazed, was obtained during the works at the castle in Sulechów and earthing up its foundations (Stachowiak 2010, 267). The sherd is made of kaolinite clays, glazed with salt glaze.

Some fragments discovered in Witków can also be considered the local imitations of the vessels of Falke's Group. Among them there are sherds of the same or two different, identical cylindrical beakers, decorated with a rhomboid stamp, with concentric smaller rhombuses within it (Fig. 4:13-15). They have bodies of a brick-red color and are covered with orange glaze on the outside. A similar fragment of a vessel was discovered at the castle in Puck in Pomerania (Starski 2009, 228, Fig. 37:7) and in Wrocław (Lower Silesia) at Katedralna Street 4, the specimen decorated with larger squares and covered with lead glazing (Mackiewicz 2012, 147, Fig. 9:d). According to M. Mackiewicz $(2012,147)$, vessels decorated with this pattern may be an imitation of the late-medieval and early modern South Moravian beakers (also known as diamond beakers), which were decorated with diamond or square stamps on their entire surface. Similar decorated vessels are kept in the collection of the Museum of Opole Silesia in Opole (Mackiewicz 2012, 147). A set 
of dishes with a similar form of decorations was found in Mazovia during the works in Pułtusk (Pela 1997, Fig. 2-5).

Another sherd also comes from the cylindrical beaker. It was made of kaolinite clay and covered with green glaze on the outside. Its entire outer surface is covered with single stamps in the form of cross, which do not form a clear pattern (Fig. 4:14). One of the cylindrical cups found in Dresden from the beginning of the 15th century was decorated with an identical stamp (Stephan 2004, 305, Fig. 18:c).

The last fragment of a vessel imitating Falke's products, obtained during excavations in Witków, is perhaps the most interesting. Despite the small size and unknown form of the vessel, it seems to be very important for the problem of imitations. It differs from Falke's products only in the brick-red color of the body and its execution in the traditional technology. The engobe, glaze and type of ornament are identical to those of the stoneware in question (Fig. 4:18). A careful examination is necessary to see the differences.

The last example of imitation in the discussed materials is a fragment of a probably cylindrical beaker, obtained during the dig in the castle in Krosno Odrzańskie. Its body has a brick-red color and a honey-colored glaze covering its outside. It is ornamented over its entire surface with triangular, opposing stamps with three and four dots in the interior (Fig. 2:7).

\section{Cultural context}

The stoneware vessels of the Falke-Group were used by various social classes. We find them in the inventories of magnates (Emperor Sigismund of Luxemburg, Prince Filip the Good, palace in Visegrád and Buda), knights (e.g. castles of Wleń, Golczewo, Buda, Daun, Bolesławiec, Działdowo, Altene, Gutštejn, Rebřík, Děvín, Köszegtejn, Solymár), clergy (the monasteries in Erfurt, Braunshausen, Stargard, Dobra Nowogardzka, Halle, Magdeburg, Cedynia), bourgeoisie (numerous finds in towns such as Wrocław, Głogów, Dresden, Brno, Poznań, Brugge, Bergen). Interestingly, single finds were also found in rural areas (Tác, Muhi in Hungary, Klein Görigk in Germany), but at the present stage of research it is difficult to accept the hypothesis that in the 15th and 16th centuries they were used by the peasants, and researchers relate their presence there with the activities of the lower clergy (Holl 1995, 215; Henker 2019, 78, Fig. 89, P1. 4:10). Most of them were found in farmland located at considerable distances from villages. Fragment from the Lower Lusatia village of Klein Görigk, from the second half of the 16th - first half of the 17th centuries is so far an isolated case (Henker 2019, 78, Fig. 89, Pl. 4:10). It seems that with each such find, a thorough analysis of the context of finding is necessary, what can illustrate the discovery from a rural settlement in Żerniki near Poznań, which was, however a part of the knightly estate (Pawlak 2007, 160).

The analyzed materials come mostly from sites inhabited by the contemporary elites. Its users probably included the family, the court and the social environment of the Piast dukes ruling the fragmented Duchy of Głogów. Several fragments and imitations were discovered in the assemblies excavated from the secondary deposit during the research of the Piast castle in Krosno Odrzańskie (Crossen), which can be dated to the 15th - beginning of the 16th centuries (Dziedzic-Kałagate 1998, 127, Pl. X:33-34). In the 15th century, the stronghold was the seat of the ducal starosts: Jan Knobelsdorf, Kasper Nebelschütz, Zygmunt Rothenburg and again Jan Knobelsdorf; after 1474, the widow of Prince Henry XI of Kożuchów, Barbara Hohenzollern, and then Princess Katarzyna von Braunschweig-Lüneburg, widow of Jan of Kostrzyn, heir of Krosno from 1535 (Nowakowski 2008, 354). Five fragments also come from the area of the former castle in Szprotawa (Sprottau), erected most likely by Henryk III of Głogów at the turn of the 13th and 14th centuries. In the 15th century it was the seat of the ducal starosts: Mikołaj Kottwitz, Jan Landeskrone, Mikołaj Warkisch, Kasper Brawn, Jerzy Nostitz and Jerzy Schöneich, and in the 1476-1488 the castle in Szprotawa was the seat of Prince Jan II of Żagań (Lewczuk 2001, 167-168; Nowakowski 2008, 392). The seat of the starosts was also the castle in 
Sulechów, where a fragment of the imitation of the Falke-Group was excavated (Nowakowski 2008, 390-391). The fragment discovered at the castle in Międzyrzecz (Fig. 3:2) can be associated with the period when the castle was home for the starosts of Międzyrzecz from the families of Nałęcz, Szamotulski and Karnkowski. This function was held by the most important officials of Polish kings, often combining it with the title of the general starost of Greater Poland (Kurnatowski 2015, 38-39). Members of the strict elite of the nobility from the close circle of the dukes of Żagań were probably users of vessels obtained during the works at the castle in Witków, near Szprotawa. Since 1419, this tower-house was owned by the von Warnsdorf family originating from the vicinity of Zittau (Michalak 2010, 167-168). Members of this family in the 15 th and early 16th centuries were trusted supporters of the princes of Żagań. After the death of the last member of the Warnsdorf line from Witków in 1548, the count of Saxony Maurice, annexed the property as a dead fief. A year later, in connection with the exchange of the Duchy of Żagań for Saxon goods, the owner of Witków, who was Emperor Ferdinand I himself, quickly sold it to his general Fabian von Schonäich. The latter, in turn, donated the property to his first wife, Euphemia Seydlitz, and later to his nephew, Georg (Michalak 2010, 173). A fragment of a cylindrical beaker, discovered during the works at the tower-house in Sękowice (Schenkendorf) near Gubin in Lower Lusatia, should be associated with the Silesian nobility. In the 15th century it was the seat of the von Wezenborg family, and at the beginning of the 16th century of Georg von Schlaberndorff, the former master of the Knights Hospitaller Order and the owner of the starostwo (administrative units) in Krosno Odrzańskie and Sulechów. After Georg von Schlaberndorff's death, it becomes the property of the Knights Hospitaller, leased by the von Arnim family (Lewczuk 2001, 166).

Special attention needs to be put on the fragments discovered in the area of Żagań (Sagan), but within the complex of the Augustinian monastery, transferred here from Nowogród Bobrzański in 1280. Purely hypothetically, these findings could be associated with the activity of two Regular Canons abbots, namely Martin Rinkenberg and Paweł Haugiewicz, when significant development of the convent and increased contacts with the princely court took place (Pobóg-Lenartowicz 1999, 206-207).

The context of the discovery of the vessels from the analyzed area indicates that they were used by richer burghers (perhaps patricians). However, the cities from which they were obtained, despite the fact that they were the capitals of lands or the seats of starosts, can hardly be considered large centers. Fragments of base parts of cylindrical beakers were discovered during the research related to draining the foundations of the Town Hall in the Międzyrzecz Market Square, which may indicate its use by city councilors or the mayor (Fig. 3:3). Let us note that a fragment of a jug of Falke-Group (Fig. 8:2; Lewczuk 2008) comes from the trench situated next to the Town Hall from the Market Square in Zielona Góra. The spherical jug imitating the Falke-Group products comes from the research on the eastern block of the market square in Kożuchów. The inventory of materials obtained during the excavation of this parcel indicates the wealth of its owners (Sikora et al. 2009, 124). Other fragments of the pear-shaped goblet were discovered during the research of the municipal parcel at Spokojna Street, near the parish church of St. John the Baptist in Międzyrzecz (Fig. 3:1; Gwoździk 2004, 88-95). From this quarter, but from the excavations conducted within the main city route near the Świebodzin Gate, comes a probable fragment of another pear-shaped goblet decorated with a unique motif of a male mask (Fig. 3:4). The archaeological context of this quarter of the city allows the vessel to be linked to the 15th and first half of the 16th centuries at the earliest (Michalak 2019, 140). Based on the discovered inventory of artefacts this quarter undoubtedly belonged to the richer part of Międzyrzecz burghers (Laszkiewicz 2003, 185-186). During the research in 2006 of the parcel around the market in Łukasiewicza Street (former Zamkowa Street) in Sulechów (Zullichau), located on the road running from the Market Square to the Castle, a fragment of a stoneware cylindrical beaker was discovered. This sherd comes from the fill of a small house with a stove made of pot tiles, which was burnt during the Sulechów fire in 1557. This date can be taken as the terminus ante quem of 
the layers associated with the household, and thus the beaker (Dziedzic 2009, 128-129, Fig 2, 4). The fragments explored in Żary (Sorau; Fig. 8:11-12) come from the parcel adjacent to the Market Square. In the years 1355-1551 the owners of Żary were the Biberstein family, and until 1765 the Schönaich family (who also ruled Witków in the 16th century) and the Promnitz family (Kowalski 1987, 245-253).

Owning and using the vessels of this group went beyond the strict elite, as their fragments are also found in city locations, which cannot be considered as prestigious places. This is the same with fragments of carelessly made jug belonging to this group, obtained during the works in the moat in Przewóz (Priebus) at the Żary Gate, which can be dated to the 15th-16th centuries. In the 13th-14th centuries, the city was in the hands of the von Pack and Bieberstein families, from 1413 it was incorporated into the Duchy of Żagań. In the period from 1472 to 1542, it belonged to the Saxon dukes (Lewczuk 2001, 166). It seems that these sherds should be associated with this period. In Zielona Góra, fragments of the pottery in question were discovered near the city walls at Kasprowicza Square, but also outside the medieval city area during research at Powstańców Wielkopolskich Square. A fragment of the cylindrical beaker appeared there in the backfill layer containing fragments of vessels from the 15th to the beginning of the 20th centuries (Dziedzic 2010, 131-132).

There are also fragments testifying the use of these vessels in rural areas, which was previously also emphasized by H. G. Stephan and I. Holl. It seems that the possibility of using these vessels by peasants cannot be absolutely ruled out. However, one should take into account the probability of getting into rural areas along with waste from nobility households or cities. This interpretation should be taken into account while trying to explain sherds found in the area of today Przewóz, however west of the city, near the Nysa Łużycka River. Other possibilities one should also bear in mind, namely such as the role and importance of the village within the knightly estate, like the village in Stare Czaple (Alt Tschöpeln), where one of the Falke-Group fragment with medieval origin was discovered. It was founded on the salt trail leading from Leipzig and Halle, through Muskau, Trzebiel, Żary and Głogów to Poznań. The clay deposits located near the village resulted in the creation of pottery workshops there. At the beginning of the 15th century, the village became the property of the Biberstein family, and then the Promnitz family, who incorporated it into the Żary-Trzebiel State. The village Chełmica (Helmsforf), where a sherd of the discussed group was also discovered, has also medieval origin. In the 15 th century the village belonged to the owners of Żary, family von Biberstein. It was not mentioned in sources until 1599, when it was a fiefdom of the estate in Brody. In the context of rural areas, there is also a collection of fragments of vessels from Luboszów (Lipschau), at the crossing of the Kwisa River, standing out from the rest of finds. The village was mentioned in sources in 1421. Discoverers associate this find with the functioning of a tavern in this area (Kałagate 2009). The above-mentioned examples seem to confirm the occasional use of vessels of Falke-Group in a rural environment, which could have been related to the aspirations of the richer representatives of the peasant state.

\section{Conclusions}

The materials discussed above allow us to confirm many hypotheses put forward in the previous works on Falke-Group ceramics.

The analyzed fragments come mainly from the contexts that can be dated on the basis of coexisting materials to the 15 th -16 th centuries. It should be emphasized that stoneware forms and their ceramic imitations were used simultaneously. It cannot be ruled out that the presence of fragments of these vessels in the younger layers (16th-18th centuries) was related to their storage in individual households for several generations (Hasse 1979, 10-15). This tendency was also observed in other sites, such as the Lower Lusatian village of Klein Görigk, where fragments of the jug of Falke-Group were discovered in a feature dated to the second half of the 16th - first half of the 17th centuries (Henker 2019, 78, Fig. 89, Pl. 4:10). 
Undoubtedly, among the analyzed fragments, the assemblage from Witków clearly stands out, presenting not only the most numerous collection, but also containing exceptionally sumptuous forms, not found anywhere else, individually produced for the owners of the castle in Witków. Perhaps it was a result of the close personal contacts of the representatives of the Warnsdorf family with Lusatia and the vicinity of Zittau.

When analyzing the spread of the artefacts, it can be noticed that very limited fragments of the Falke-Group were found in the northern part of the area in question. However, finds of vessels of this group are known from both Western Pomerania and Greater Poland, hence we would associate this lack with the state of archaeological research rather than with the actual absence of their use in this area. The greater spread of these artefacts in this area would be favored by the Brandenburg takeover of the areas belonging to the Duchy of Żagan at the end of the 15th century (Fig. 1). In this context, we can expect finds of fragments of Krausen (bag-shaped vessels), common in Brandenburg and Saxony (cf. Rode 1999, 52; Stephan 2004, 307).

Numerous finds of fragments of the Falke-Group in Lusatia and the adjacent lands, in the close circle of operation of Lusatian workshops, should not be too surprising. It seems that due to not distant location of the ateliers in these areas, one can also expect a demand for dishes not of the highest quality, which did not meet high standards, but could be used by the less wealthy

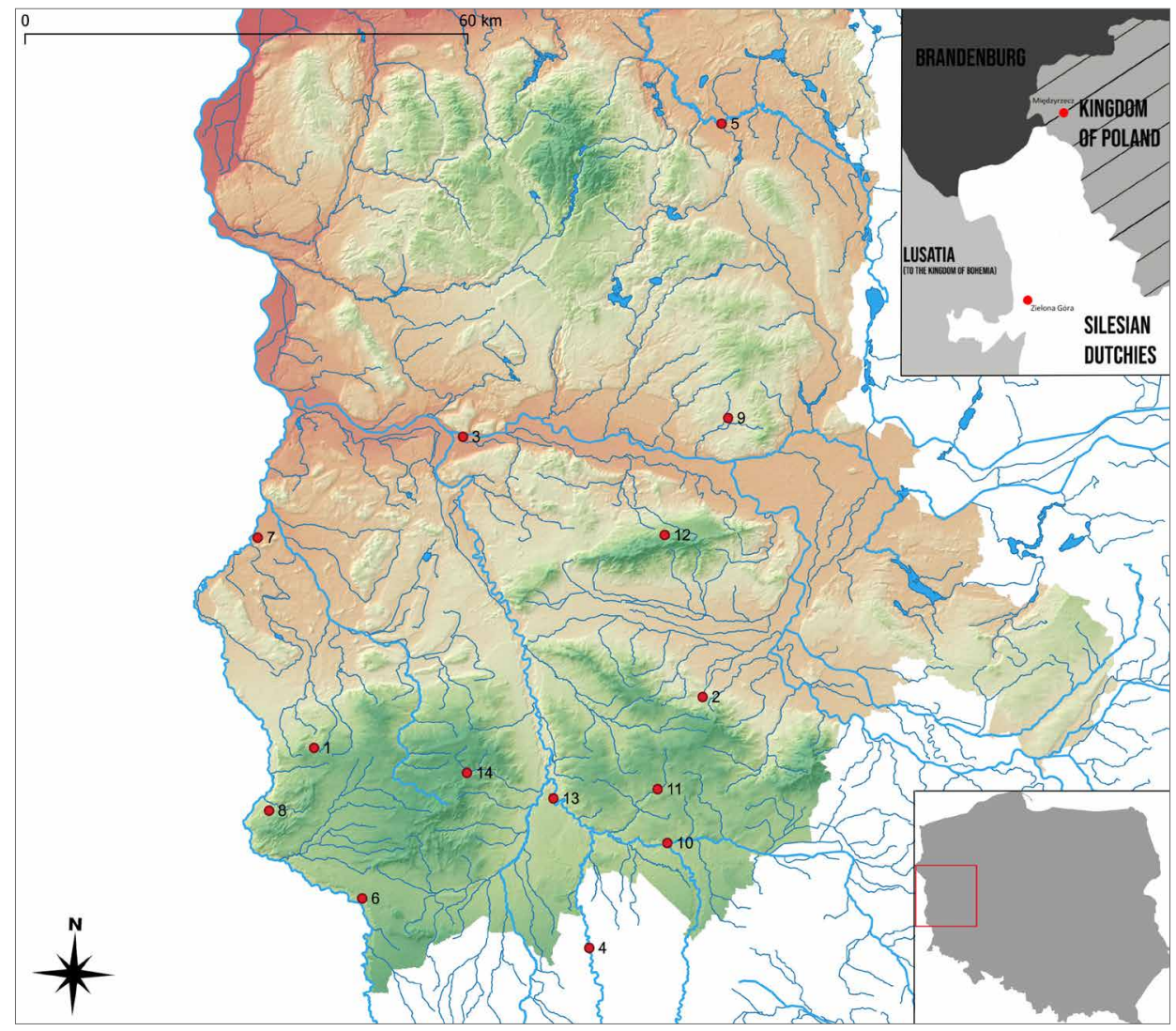

Fig. 1. Distribution of the finds of the Falke-Group ceramics in the borderland of Silesia, Greater Poland, Brandenburg and Lusatia in the 15th-16th century against the political situation. The numbers correspond with the catalogue at the end. Elaborated by B. Gruszka, A. Michalak.

Obr. 1. Rozložení nálezů keramiky Falkeho skupiny na pomezí Slezska, Velkopolska, Braniborska a Lužice na pozadí politického uspořádání v 15.-16. století. Čísla odpovídají katalogu na konci textu. Nákres B. Gruszka, A. Michalak. 
representatives of the social ladder of that time. Undoubtedly, along with the distance from the place where the vessels were made, their price increased and the frequency of their occurrence decreased, but at the same time the prestige resulting from their possession increased (Miller 1987, 135-136). Significant differences in the quality of the vessels indicate the existence of greater production taking place most likely in several workshops as well as locations, perhaps longer than previously thought (Stephan 2004, 302; Henker 2019, 78, Fig. 89, Pl. 4:10). There is no doubt that the water network of the Elbe and the Oder was used for distribution, enabling a direct connection with the Baltic Sea (Gaimster 1999, 63). The extensive distribution area of this unique type of vessel is probably associated with the mobility of the commercial and aristocratic elites in the Hanseatic trade area and in the countries of the Luxembourg dynasty (Stephan, Gaimster 2002, 156).

\section{Acknowledgements}

We would like to thank Mrs. Anna Jaskulska, Bieniów, Piotr Wawrzyniak, Poznań and Hubert Augustyniak, Świebodzin, Karol Błaszczyk, Szprotawa, Paweł Stachowiak, Sulechów, Piotr Dziedzic, Zielona Góra for making available materials from their research. Last, but not least, we are also indebt to Marcin Kosowicz from Voivodeship Office for the Protection of Monuments in Zielona Góra and Christof Krauskopf from BLDAM Brandenburg for their help in accessing hardly available literature.

\section{Catalogue of Finds}

\section{Chelmica, Tuplice commune, Żary district}

Find place, site 10 (PAR 68-08/64); rural, field (surface survey in 1994); acc. no. 7156/94.

Description: fragment of belly from the pear-shaped beaker, decorated with single square stamps with four dots in the interior, creating opposite triangles, exterior covered with brown slip and salt glaze, grey stoneware (Fig. 2:1).

Chronology: 15th-16th cent.

References: unpublished.

\section{Kożuchów, Kożuchów commune, Nowa Sól district}

Find place: site 5 (PAR 66-15/7), town (excavations in 2008-2009), fill of the latrine, feature no 4.

Description: vessel imitating Falke-Group products; jug with low-placed recess of the belly, cone neck, vertically placed, profiled rim and band-like handle; decorated on almost entire surface, transition zones of rim and belly into neck underlined with plastic, grooved roller; rim decorated with band made of knurl (diagonal oblongs); neck is covered with diagonal bands created from single, square stamps with four dots in the interior, the transition area between neck and belly was embellished with three molded medallions with the depiction of: bird, male/young man and bearded man; belly ornamented on entire surface with single squares with four dots in the interior, creating the system of broken lines and rhombuses between them; white-grey clay (kaolin); exterior covered with green glaze (Fig. 2:2).

Chronology: late 15th-16th cent.

References: Wawrzyniak 2012, 153, 156, Fig. 18. 

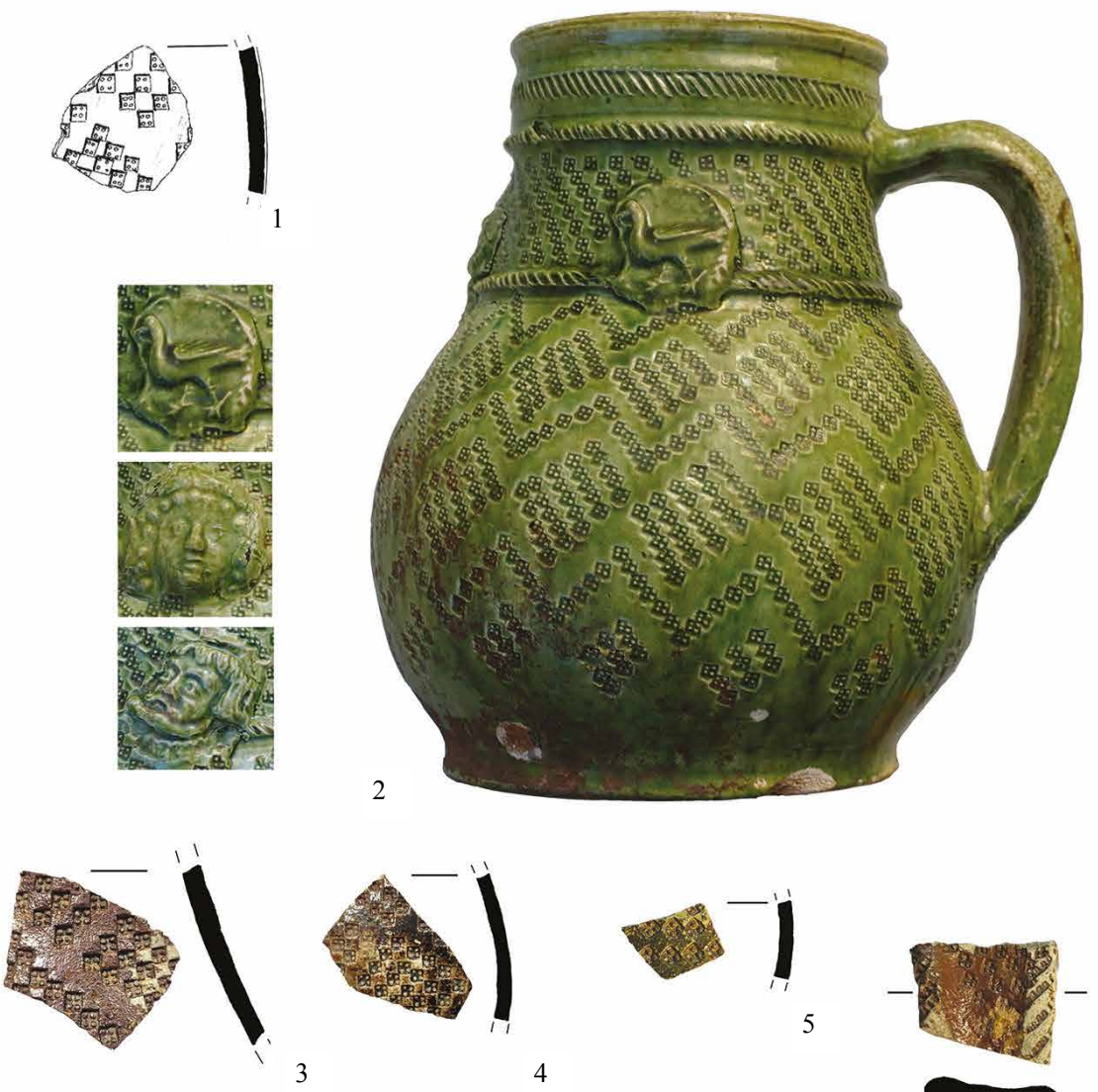

4
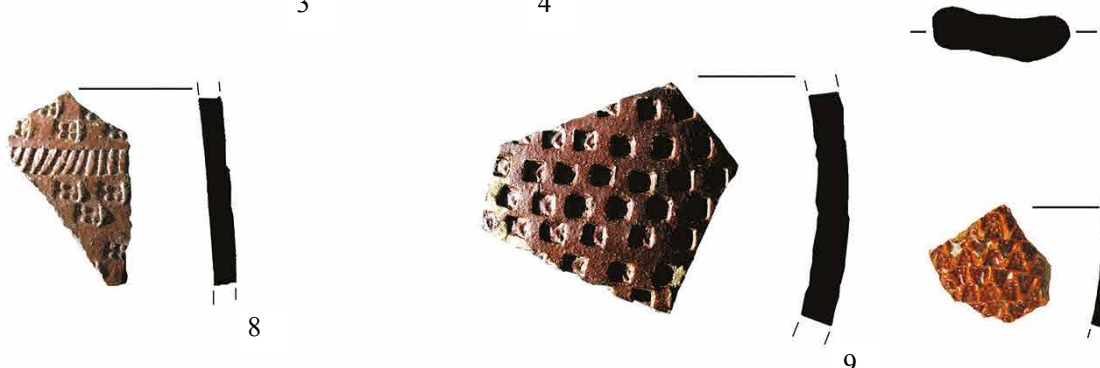

6
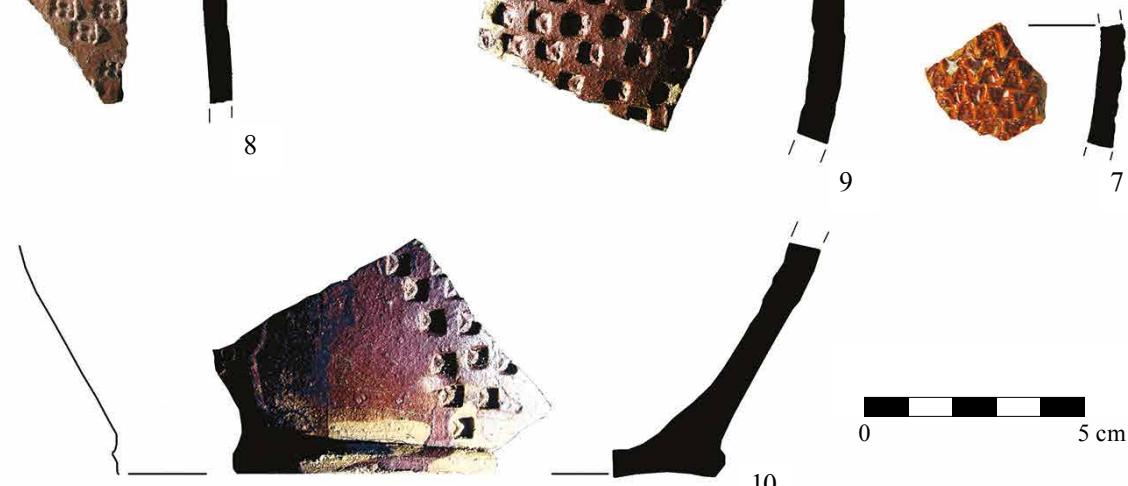

9

7

Fig. 2. Falke-Group ceramics from analysed area. 1 - Chełmica (cat. 1); 2 - Kożuchów (cat. 2); 3-7 - Krosno Odrzańskie (cat. 3); 8-10 - Luboszów (cat. 4). Drawing and photo by $S$. Kałagate.

Obr. 2. Keramika Falkeho skupiny z analyzované oblasti. 1 - Chełmica (kat. 1); 2 - Kożuchów (kat. 2); 3-7 - Krosno Odrzańskie (kat. 3); 8-10 - Luboszów (kat. 4). Kresba a foto S. Kałagate. 


\section{Krosno Odrzańskie, Krosno Odrzańskie commune, Krosno Odrzańskie district}

Find place: site 11 (PAR 59-10/45), castle (excavations in 1998), trench 1; acc. no. 4/98, 9/98, $10 / 98,29 / 98$.

Description: 5 fragments, including: 1 small fragment of belly from uncertain vessel decorated with single, square stamps with four dots in the interior; brown slip, salt glaze; light-grey stoneware (Fig. 2:5); 1 fragment of belt-like handle from jug, decorated with single, square stamps with four dots in the interior, limited with bands of punctures appearing on the edge of the handle; brown slip, salt glaze; light-grey stoneware (Fig. 2:6); 2 fragments of bellies from jugs, decorated with single, square stamps with four dots in the interior, in the system of rhombuses; brown slip, salt glaze; grey stoneware (Fig. 2:3-4); 1 fragment of vessel imitating Falke-Group products piece of belly from cylindrical beaker; red earthenware, covered from outside with honey-color glaze, decorated on entire surface with triangular, opposite stamps with three and four dots in the interior (Fig. 2:7).

Chronology: late 15th-16th cent.

References: Dziedzic-Kałagate 2002, 127, 163, 185, Pl. X:33-34, XXXII:29.

\section{Luboszów, Osiecznica commune, Boleslawiec district}

Find place: site 2 (PAR 72-13/4); forest by the Kwisa River - remains of the tavern (?; excavations in 2004).

Description: 3 fragments from two vessels: 1 fragment of jug neck covered with square stamps with four dots in the interior, separated with horizontal bands made with using knurl, brown slip, salt glaze; light-grey stoneware (Fig. 2:8); 2 fragments of jug, including: 1 fragment of belly decorated with single, square stamps with raised cross in interior; brown, with cherry shade, slip, salt glaze; light-grey with olive shade stoneware; 1 fragment of lower part with separated base, with pedestal and slightly visible (effaced) traces of removal, decorated with stamps with cross in interior, creating system of hanging triangle; brown, with cherry shade, slip, salt glaze; light-grey wit olive shade stoneware (Fig. 2:9-10).

Chronology: 15th-16th cent.

References: Kałagate 2008, 389-390, 395, photo 1-3, Pl. I:6-8.

\section{Międzyrzecz, Międzyrzecz commune, Międzyrzecz district}

I. Find place: site 1c (PAR 51-15/134); Old Market Square-Town Hall, trench connected with works on foundations of the Town Hall (excavations in 2002).

Description: small fragment of lower part of cylindrical beaker with flat base, separated into broad and highly angled, frilled formed pedestal, walls of the vessel on entire preserved height decorated with narrow horizontal riling, red-brown-violet slip, salt glaze; dark-grey stoneware (Fig. 3:3).

Chronology: 15 th - first half of the 16th cent.

References: Gwoździk 2004, 92-93. 

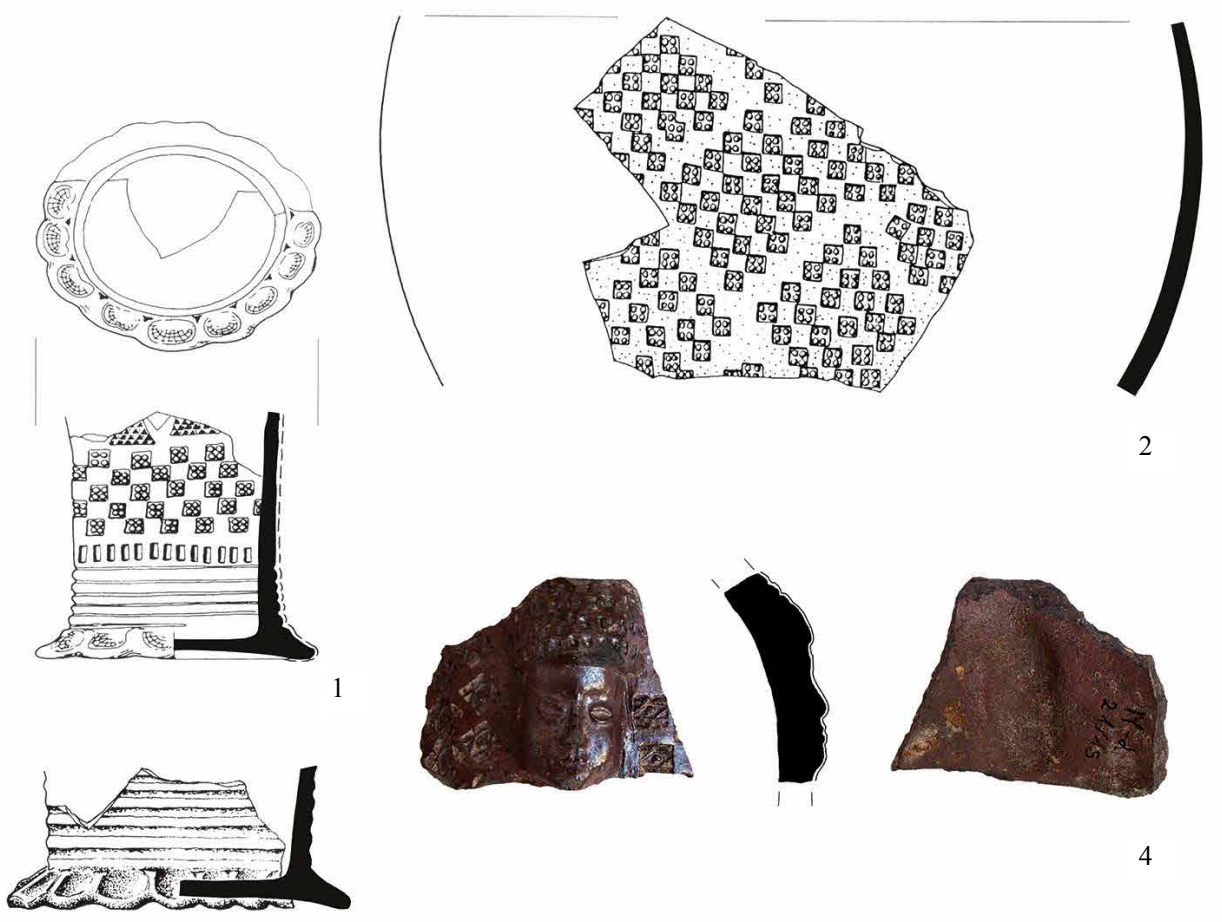

4

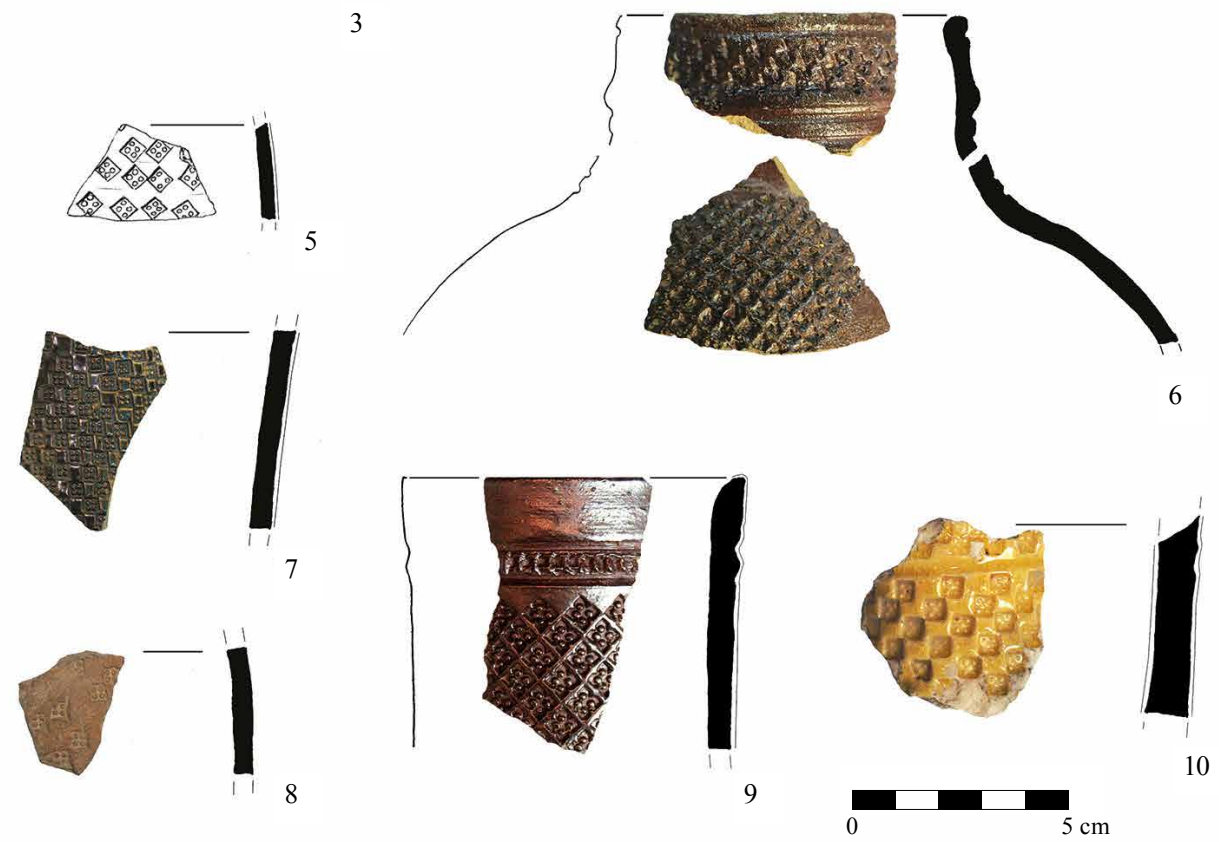

Fig. 3. Falke-Group ceramics from analysed area. 1-4 - Międzyrzecz (cat. 5); 5-6 - Przewóz (cat. 6); 7 - Sękowice (cat. 7); 8-Stare Czaple (cat. 8); 9-10 - Sulechów (cat. 9). 1-3 after Gwoździk 2004; 4-10 drawing and photo by S. Kalagate.

Obr. 3. Keramika Falkeho skupiny z analyzované oblasti. 1-4 - Międzyrzecz (kat. 5); 5-6 - Przewóz (kat. 6); 7 - Sękowice (kat. 7); 8 - Stare Czaple (kat. 8); 9-10 - Sulechów (kat. 9). 1-3 podle Gwoździk 2004; 4-10 kresba a foto S. Kałagate. 
II. Find place: site 1 (PAR 51-15/33), castle, architectural-preservation works connected with clearing the rubble from the castle in $1950 \mathrm{~s}$.

Description: 4 fragments from the lower part of cylindrical beaker, with flat base separated into broad and highly angled, frilled formed pedestal, walls of the vessel on entire preserved height decorated with narrow horizontal riling, separated with vertical band of incised oblongs, above the zone decorated with row of single, square stamps with four dots in the interior, separated with squares without decoration, dark-brown slip, salt glaze; grey stoneware (Fig. 3:1).

Chronology: 15 th - first half of the 16th cent.

References: Gwoździk 2004, 93-94.

III. Find place: site 1c (PAR 51-15/134), town, parcel 290/26 and 291, sector B3, layer 7/2, sector B3, layer 8/1+3 (excavations in 2000), acc. no. 81/00; 95/00.

Description: 3 fragments most likely from the jug (?), exterior decorated with multiple rhomboid fields created from 25 incised square stamps with four dots in the interior, separated with four-sided fields without decoration, brown with red shade, slip, salt glaze; light-grey stoneware (Fig. 3:2).

Chronology: first half of the 15th cent.

References: Gwoździk 2004, 95.

IV. Find place: site 1c (PAR 51-15/134), town, Mieszka I Street (archaeological supervision in 2015); acc. no. 21/15.

Description: 1 fragment of upper part of the belly of pear-shaped goblet or jug with molded application with female or young male head with headgear (perhaps schematically depicted hair); on both side of applique, rhomboid stamps with raised, diagonal grid in the interior; brown with cherry shade slip, salt glaze; dark-grey stoneware (Fig. 3:4).

Chronology: 15th-16th cent.

References: unpublished.

\section{Przewóz, Przewóz commune, Żary district}

I. Find place: site 3 (PAR 71-09/3), town, moat (excavations in 1993), trench I, acc. no. 1421/93.

Description: 4 fragments of upper part of jug, cylindrical neck decorated with three horizontal rows of crosses, separated from the edge with single groove and from the belly with plastic rib and two horizontal grooves; upper part of the belly decorated with the pattern of hanging triangle created from single, square stamps with cross in the interior; dark-brown slip; salt glaze (on both sides of the vessel); light-grey with brown shade stoneware (Fig. 3:6).

Chronology: 15th-16th cent.

References: Magda-Nawrocka 1995, 212, Fig. 4:5. 
II. Find place: site 22 (PAR 71-09/30); rural, field (surface survey in 1994), acc. no. 7344/94.

Description: fragment of belly of uncertain vessel decorated with single square stamps with four dots in the interior; dark-brown slip and salt glaze; light-grey stoneware (Fig. 3:5).

Chronology: 15th-16th cent.

References: unpublished.

\section{Sękowice, Gubin commune, Krosno Odrzańskie district}

Find place: site 11 (PAR 62-06/13), tower-house, (excavations in 1996), trench 2, acc. no. 14 /96.

Description: fragment of the belly from pear-shaped goblet, decorated with single, small, square stamps with four dots in the interior; dark-brown slip, salt glaze; light-grey stoneware (Fig. 3:7).

Chronology: 15th-16th cent.

References: unpublished.

\section{Stare Czaple, Trzebiel commune, Żary district}

Find place: site 15 (PAR 69-07/52), rural, field (surface survey in 1994), acc. no. 7265/94.

Description: fragment of the belly of uncertain vessel decorated with single, square stamps with four dots in the interior, without any clear pattern, exterior secondarily fired, brown, without glaze; grey stoneware (Fig. 3:8).

Chronology: 15th-16th cent.

References: unpublished.

\section{Sulechów, Sulechów commune, Żary district}

I. Find place: site 24 (PAR 59-15/40), town (excavations in 2006), trench C, layer 5, acc. no. 14/06, $87 / 06$.

Description: 2 fragments, including: 1 fragment of upper part of cylindrical beaker; transition between neck and belly underlined with the band made with using knurl, separated from both sides with horizontal groove, belly decorated with single, square stamps with four dots in the interior; dark-brown slip, salt glaze; grey stoneware; interior, secondary fired (Fig. 3:9); 1 fragment from the imitation of the Falke-Group - piece of the belly of cylindrical beaker; white stoneware (kaolin clay) on both sides covered with yellow glaze; decorated with single horizontal riling, separating fields entirely covered with single, square stamps with five dots in the interior (diagonal bands; Fig. 3:10).

Chronology: 15th-16th cent. (before 1557).

References: Dziedzic 2009, 129-131, Fig. 5-7.

II. Find place: site 24 (PAR 59-15/40), castle (excavations in 2009). 
Description: 1 fragment from the imitation of the Falke-Group - piece of the belly of cylindrical beaker; white stoneware (kaolin clay) on both sides covered with yellow glaze; decorated with single horizontal riling, separating fields entirely covered with single, square stamps with four dots in the interior.

Chronology: 15th-16th cent.

References: unpublished.

\section{Szprotawa, Szprotawa commune, Żagań district}

Find place: site 17 (PAR 70-14/62), area of former castle, now remains of evangelic church (accidental finds in 2004-2006).

Description: 5 fragments from two-three vessels, including: 1 fragment of upper part of cylindrical beaker, rim slightly deflected to the exterior, its transition into belly underlined by plastic roller, decorated with knurl, below single, square stamps with four dots in the interior; brown, of cherry shade, slip, salt glaze; grey stoneware (Fig. 4:1); 1 fragment of lower part of cylindrical beaker with frilled base, decorated with riling; brown slip, salt glaze; grey stoneware (Fig. 4:2); 2 fragments (most likely from the same vessel) of lower part of cylindrical beaker, decorated with riling and in the upper part, with single square stamps with four dots in the interior; brown slip, salt glaze (Fig. 4:4-5); 1 fragment of belly of uncertain vessel, covered with square stamps with four dots in the interior; brown slip, salt glaze (Fig. 4:3).

Chronology: 15th-16th cent.

References: unpublished.

\section{Witków, Szprotawa commune, Żagań district}

Find place: site 6 (PAR 68-14/37), castle complex (excavations in 1978, 2020), trench VIII B1, stratum 15; acc. no. 45/95.

Description: 83 fragments, belonging to unspecified number of vessels, including: 4 fragments of highly decorated lid, handle in form of stylized flower, which stand in the center of engraved petals, the center of each of them is decorated with circular stamp with 7 dots in the interior; edge of the lid is decorated with row of incised rectangles made with using knurl; brown surface, fired covered with salt glaze; light-grey stoneware with olive shade (Fig. 5:10); 1 fragment of molded application with female or young male; below the face a row of incised circles; brown slip, salt glaze; grey stoneware (Fig. 5:11); 1 fragment of upper part of uncertain vessel (jug ?), cylindrical neck decorated with riling and band of stamps incised with using knurl, upper part of the belly ornamented with band of vertical oblongs made with using knurl, below row of single, square stamps with four dots in the interior, creating the system of triangles, brown slip, salt glaze; light-grey stoneware (Fig. 5:12); 1 fragment of triangular, element of anthropomorphic vessel in form of a pointed shoed on wooden patten (?); brown slip, salt glaze; light-grey stoneware (Fig. 5:13); 1 fragment of vessel with two distinct ribs, element of anthropomorphic vessel in form of a pointed shoed on wooden patten (?); brown slip, salt glaze; light-grey stoneware (Fig. 5:14);

2 fragments of upper part of pear-shaped goblet, densely decorated, transition between neck and belly is underlined by plastic, pleated rib, below three bands of single, square stamps with four dots in the interior, below the band of opposite triangular stamps with raised triangles in the interior; brown slip, salt glaze; grey stoneware (Fig. 5:1); 1 fragment of rim of the pear-shaped goblet; brown 

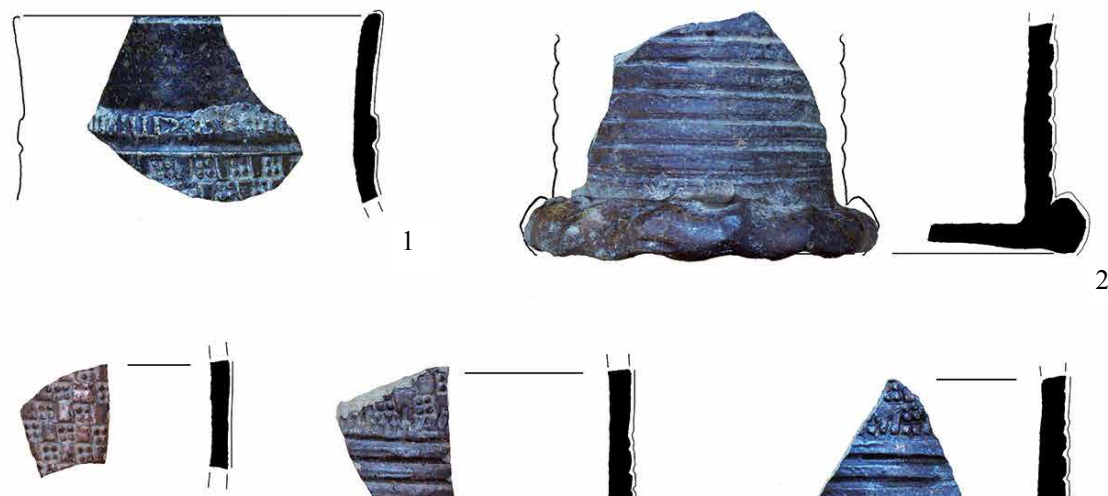

3
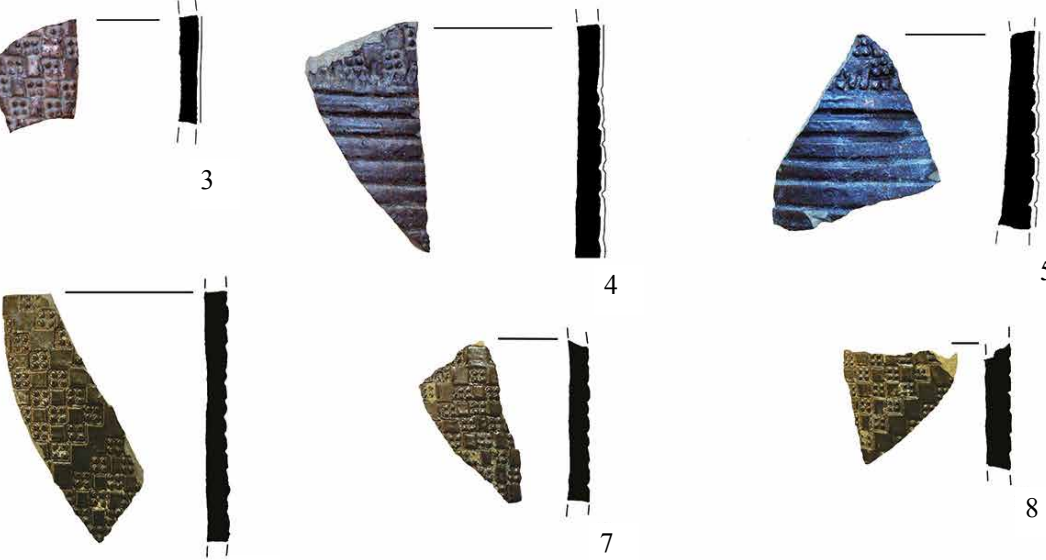

7

6

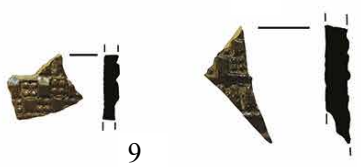

10

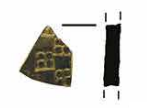

11

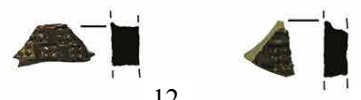

13
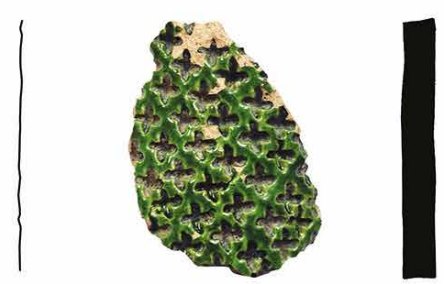

14
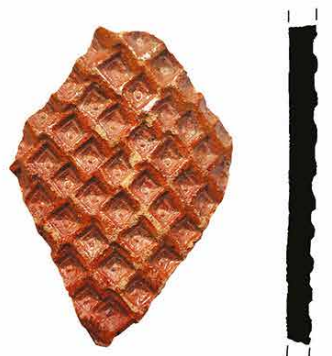

15
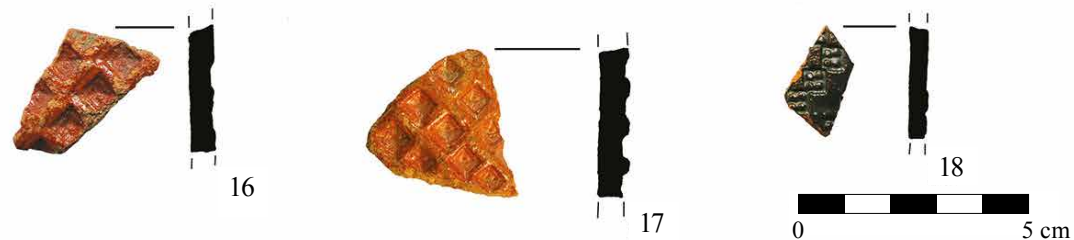

Fig. 4. Falke-Group ceramics from analysed area. 1-5 - Szprotawa (cat. 10); 6-18 - Witków (cat. 11). Drawing and photo by S. Kalagate.

Obr. 4. Keramika Falkeho skupiny $z$ analyzované oblasti. 1-5 - Szprotawa (kat. 10); 6-18 - Witków (kat. 11). Kresba a foto S. Kalagate. 

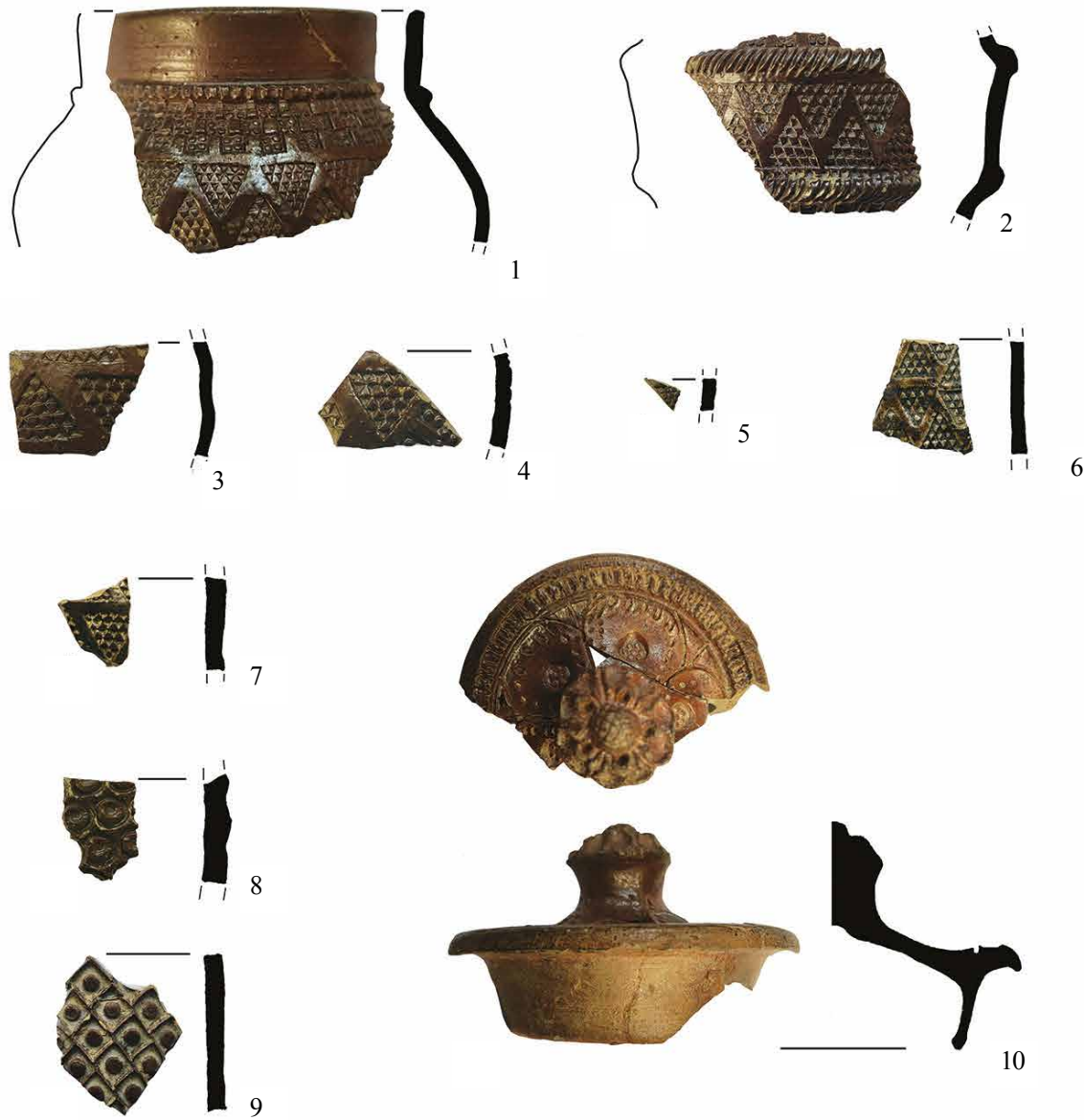

9
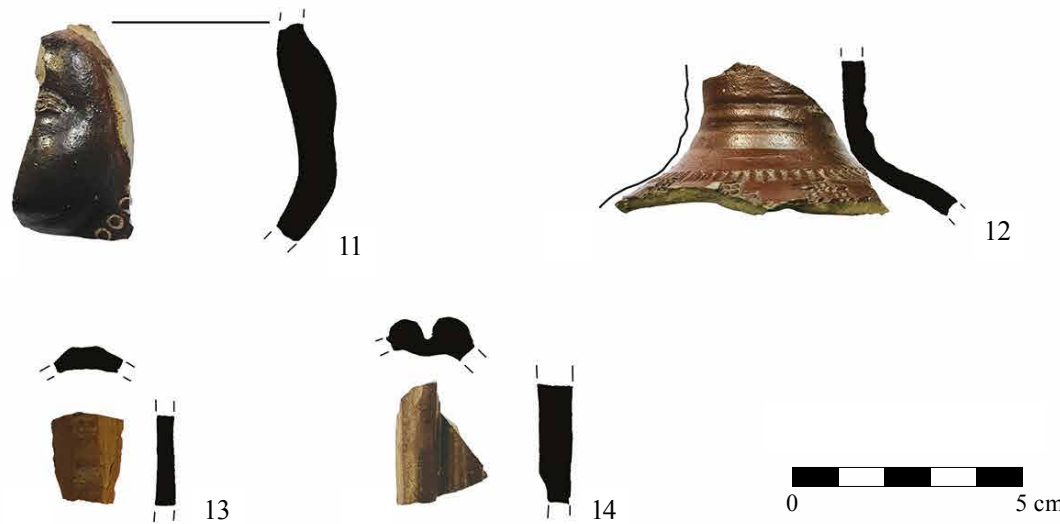

Fig. 5. Falke-Group ceramics from analysed area. 1-14 - Witków (cat. 11). Drawing and photo by S. Kalagate. Obr. 5. Keramika Falkeho skupiny z analyzované oblasti. 1-14 - Witków (kat. 11). Kresba a foto S. Kalagate. 
exterior, fired, covered with salt glaze; grey stoneware (Fig. 6:7); 1 fragment of rim of pear-shaped goblet (?); dark-brown slip, salt glaze; grey stoneware (Fig. 6:2); 1 fragment of rim of pear-shaped goblet (?); dark-brown slip, salt glaze; grey stoneware (Fig. 6:3); 2 fragments of belly of pear-shaped goblet, decorated with single triangular stamps with raised triangles in the interior, in opposite arrangement, on both sides separated by rollers with incisions and punctures, above and below the rollers, single square stamps with four dots in the interior, without clear arrangement; brown slip, salt glaze; grey stoneware (Fig. 5:2); 2 fragments of upper part of pear-shaped goblet (?), in the transition zone between rim and belly decorated with plastic, fluted ribbon, fired exterior, brown, covered with salt glaze; light-grey stoneware (Fig. 6:6); 1 fragment of upper part of pear-shaped goblet (?) decorated with roller with incisions, punctures and diagonal oblongs made with using knurl; brown with cherry shade slip, salt glaze; grey stoneware (Fig. 7:12); 1 fragment of upper part of the belly of pear-shaped goblet decorated with incised band made with using knurl; brown slip, salt glaze; grey stoneware (Fig. 7:15); 1 fragment of lower part of belly from pear-shaped goblet, decorated with single, square stamps with four dots in the interior, in the opposite triangles arrangement (?); brown slip, salt glaze; light-grey stoneware (Fig. 7:5); 1 fragment of belly from pear-shaped goblet, decorated with pleated roller and single, square stamps with four dots in the interior, in the opposite triangles arrangement; brown slip, salt glaze; dark-grey stoneware (Fig. 7:14); 1 fragment of belly from pear-shaped goblet, decorated with single, square stamps with four dots in the interior, in the opposite triangles arrangement; brown slip, salt glaze; light-grey stoneware (Fig. 7:13); 1 fragment of belly from pear-shaped goblet, covered with single, square stamps with four dots in the interior, without any clear arrangement; dark-brown slip, salt glaze, light-grey stoneware (Fig. 7:9); 1 fragment of pear-shaped goblet, covered with single, square stamps with four dots in the interior, without any clear arrangement; dark-brown slip, salt glaze, light-grey stoneware (Fig. 7:7); 3 fragments of bellies from pear-shaped goblet (from the same vessel) decorated with band of opposite triangles made with using triangular stamp with raised triangles in the interior; brown slip, salt glaze; grey stoneware (Fig. 5:3-5); 1 fragment of belly from pear-shaped goblet, decorated with band of opposite triangles made with using triangular stamp with raised triangles in the interior; brown slip, salt glaze; grey stoneware; 1 fragment of belly from pear-shaped goblet, decorated with band of opposite triangles made with using triangular stamp with raised triangles in the interior, brown slip, salt glaze; grey stoneware (Fig. 5:7); 1 fragment of belly from pear-shaped goblet, decorated with band of opposite triangles, triangular stamp with raised triangles in the interior (3 rows); brown slip, salt glaze; light-grey stoneware (Fig. 5:6); 1 fragment of belly from pear-shaped goblet, decorated with single, square stamps with four dots in the interior and triangular stamp with raised triangles in the interior; brown slip, salt glaze; grey stoneware (Fig. 7:8); 1 fragment of belly from pearshaped goblet, decorated with single, square stamps with four dots in the interior; brown slip, salt glaze; grey stoneware (Fig. 7:6); 1 fragment of upper part of the belly from pear-shaped goblet (?) decorated with punctures; brown slip, salt glaze; light-grey stoneware (Fig. 7:11);

1 fragment of rim from cylindrical beaker, decorated with fluted roller; brown exterior, fired, covered with salt glaze; grey stoneware with olive shade (Fig. 6:5); 1 fragment of rim from cylindrical beaker (?), decorated with fluted roller; covered in the exterior with brown slip and salt glaze; grey stoneware (Fig. 6:4); 1 fragment of rim from cylindrical beaker; dark-brown slip, salt glaze; light-grey stoneware of olive shade (Fig. 6:1); 3 fragments of belly from cylindrical beaker covered with single, square stamps with four dots in the interior; dark-brown slip, salt glaze, light-grey stoneware (Fig. 7:17); 1 fragment of belly from cylindrical beaker covered with single, square stamps with four dots in the interior; brown slip, salt glaze, grey stoneware (Fig. 7:23); 1 fragment of belly from cylindrical beaker covered with single, square stamps with four dots in the interior; brown slip, salt glaze, grey-olive stoneware (Fig. 7:24); 1 fragment of belly from cylindrical beaker covered with single, square stamps with four dots in the interior; dark-brown slip, salt glaze, grey stoneware (Fig. 7:25); 1 fragment of belly from cylindrical beaker covered with single, square stamps with four dots in the interior; dark-brown slip, salt glaze, grey stoneware (Fig. 7:22); 1 fragment of belly from cylindrical beaker, decorated with single, square stamps with four dots in 

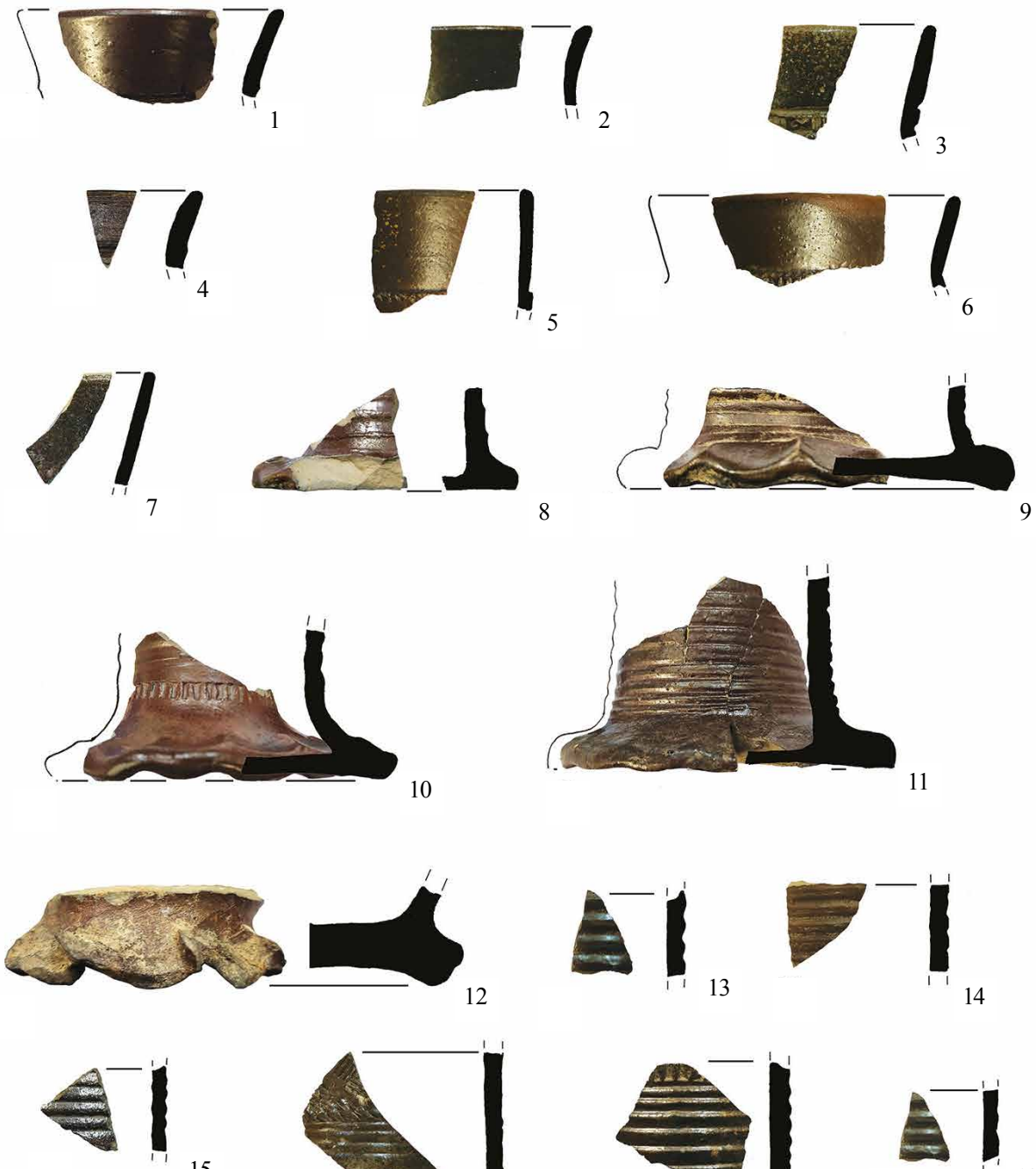

15
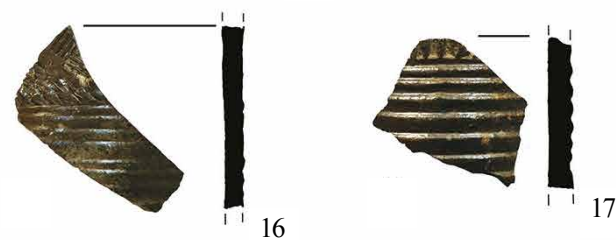

14
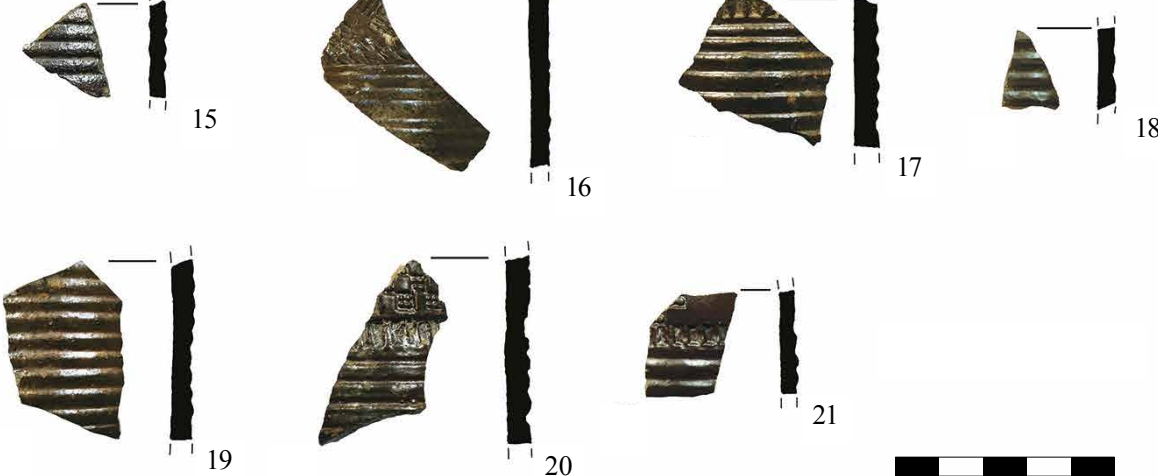

Fig. 6. Falke-Group ceramics from analysed area. 1-21 - Witków (cat. 11). Drawing and photo by S. Kalagate. Obr. 6. Keramika Falkeho skupiny z analyzované oblasti. 1-21 - Witków (kat. 11). Kresba a foto S. Kalagate. 
the interior; dark-brown slip, salt glaze, light-grey stoneware (Fig. 7:18); 1 fragment of belly from cylindrical beaker decorated with single, square stamps with four dots in the interior; dark-brown slip, salt glaze, grey stoneware (Fig. 7:18); 1 fragment of belly from cylindrical beaker decorated with single, square stamps with four dots in the interior; dark-brown slip, salt glaze, grey stoneware (Fig. 7:19); 1 fragment of belly from cylindrical beaker decorated with single, square stamps with four dots in the interior and triangular stamp with raised triangles in the interior; dark-brown slip, salt glaze, grey stoneware (Fig. 7:20); 1 fragment of belly from cylindrical beaker covered with single, square stamps with four dots in the interior, in the system of opposite triangles and band of vertical oblongs made with using knurl; brown slip, salt glaze, olive-grey stoneware (Fig. 7:26); 1 fragment of belly from cylindrical beaker decorated with single, square stamps with four dots in the interior; brown slip, salt glaze; light-grey stoneware; 1 fragment of belly from pear-shaped goblet decorated with single, square stamps with four dots in the interior, in the arrangement of opposite triangles; brown slip, salt glaze; grey stoneware (Fig. 4:6); 1 fragment of belly from cylindrical beaker decorated with single, square stamps with four dots in the interior; brown slip, salt glaze; light-grey stoneware of olive shade (Fig. 4:7); 1 fragment of belly from pear-shaped goblet decorated with single, square stamps with four dots in the interior; brown slip, salt glaze; light-grey stoneware (Fig. 4:8); 1 fragment of belly from cylindrical beaker decorated with network ornament, in each rhombus a single raised fot in the center; dark-brown slip, salt glaze; grey stoneware (Fig. 5:9); 1 fragment of belly from cylindrical beaker decorated with rows of circular stamps; dark-brown slip, salt glaze; light-grey stoneware (Fig. 5:8); 1 fragment of lower part from cylindrical beaker decorated with horizontal grooves; dark-brown slip, salt glaze; light-grey stoneware; 1 fragment of lower part from cylindrical beaker decorated with horizontal grooves; dark-brown slip, salt glaze; grey stoneware (Fig. 6:13); 1 fragment of lower part from cylindrical beaker decorated with horizontal grooves; dark-brown slip, salt glaze; grey stoneware (Fig. 6:14); 1 fragment of lower part from cylindrical beaker decorated with horizontal grooves and band of vertical oblongs made with using knurl; dark-brown slip, salt glaze; light-grey stoneware (Fig. 6:17); 1 fragment of lower part from cylindrical beaker decorated with horizontal grooves; dark-brown slip, salt glaze; dark-grey stoneware (Fig. 6:15); 1 fragment of lower part of cylindrical beaker decorated with horizontal grooves and band of vertical oblongs incised with using knurl and single, square stamps with four dots in the interior, in the system of hanging triangles; brown slip, salt glaze; light-grey stoneware (Fig. 6:21); 1 fragment of lower part of cylindrical beaker decorated with horizontal grooves; dark-brown slip, salt glaze; grey stoneware (Fig. 7:4); 1 fragment of lower part of cylindrical beaker decorated with horizontal grooves; dark-brown slip, salt glaze; grey stoneware (Fig. 6:19); 1 fragment of lower part of cylindrical beaker decorated with horizontal grooves and band of vertical oblongs made with using knurl and single, square stamps with four dots in the interior; dark-brown slip, salt glaze; light-grey stoneware (Fig. 6:20); 2 fragments of lower part of cylindrical beaker, decorated with horizontal grooves, above them two bands of punctures and rhombuses created from short lines; brown slip, salt glaze; grey stoneware (Fig. 6:16; 7:10); 1 fragment of lower part of cylindrical beaker decorated with horizontal grooves, band of vertical oblongs incised with using knurl and single, square stamps with four dots in the interior; dark-brown slip, salt glaze; grey stoneware (Fig. 7:1); 1 fragment of lower part of cylindrical beaker decorated with horizontal grooves, band of vertical oblongs incised with using knurl and single, square stamps with four dots in the interior; dark-brown slip, salt glaze; grey stoneware (Fig. 7:2); 1 fragment of lower part of cylindrical beaker decorated horizontal grooves; dark-brown slip, salt glaze; grey stoneware (Fig. 7:3); 1 fragment of lower part of cylindrical beaker decorated with band of vertical oblongs incised with using knurl and square stamps with four dots in the interior, in the opposite triangles arrangement; dark-brown with cherry shade slip, salt glaze; grey stoneware (Fig. 7:27); 1 fragment of lower part of cylindrical beaker decorated with horizontal grooves, band of vertical oblongs incised with using knurl and single, square stamps with four dots in the interior; dark-brown slip, salt glaze; grey stoneware (Fig. 4:10); 1 fragment of frilled base of cylindrical beaker (?); base part decorated with horizontal grooves; dark-brown slip, salt glaze; light-grey stoneware (Fig. 6:9); 1 fragment of 

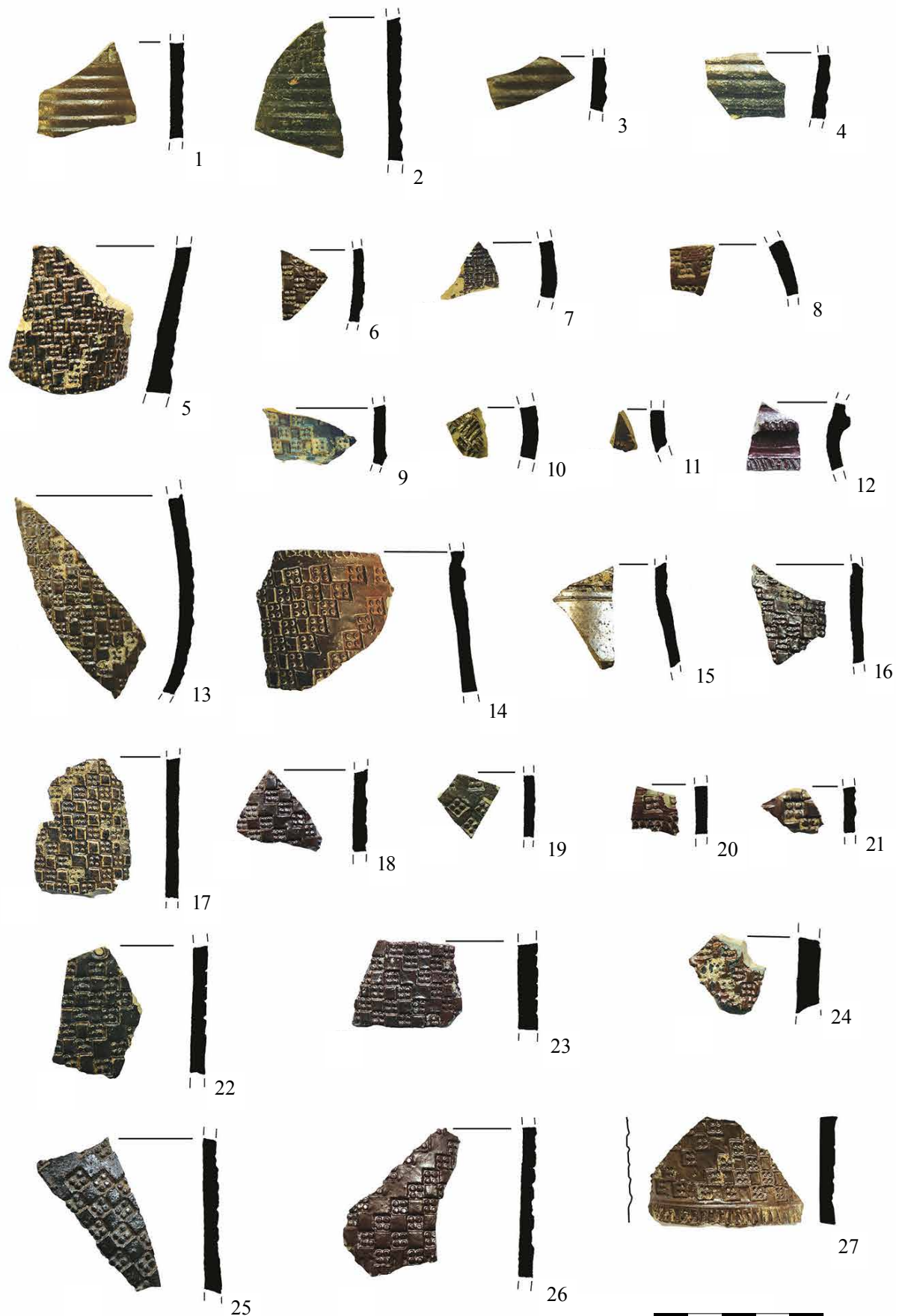

25

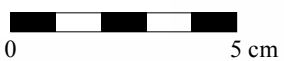

Fig. 7. Falke-group ceramics from analysed area. 1-28 - Witków (cat. 11). Drawing and photo by S. Kalagate. Obr. 7. Keramika Falkeho skupiny z analyzované oblasti. 1-28 - Witków (kat. 11). Kresba a foto S. Kałagate. 
frilled base of cylindrical beaker (?); base part decorated with horizontal grooves; dark-brown slip, salt glaze; light-grey stoneware (Fig. 6:8); 1 frilled base of cylindrical beaker (?); brown slip (?), salt glaze; beige-colored-grey stoneware (Fig. 6:12); 1 fragment of frilled base of cylindrical beaker (?); base part decorated with horizontal grooves; dark-brown slip, salt glaze; light-grey stoneware (Fig. 6:10); 3 fragments of frilled base of cylindrical beaker (?); base part decorated with horizontal grooves; dark-brown slip, salt glaze; light-grey stoneware (Fig. 6:11);

1 small fragment of belly from unspecified vessel decorated with single, square stamps with four dots in the interior; brown slip, salt glaze, light-grey stoneware (Fig. 7:21); 1 small fragment of belly from uncertain vessel decorated with single, square stamps with four dots in the interior; brown slip, salt glaze, light-grey stoneware (Fig. 4:9); 1 small fragment of belly from uncertain vessel, decorated with single, square stamps with four dots in the interior; dark-brown slip, salt glaze, grey stoneware (Fig. 4:11); 1 small fragment of belly from uncertain vessel decorated with single, square stamps with four dots in the interior; brown slip, salt glaze, grey stoneware (Fig. 4:12); 1 small fragment of belly from uncertain vessel, decorated with single, square stamps with four dots in the interior; dark-brown slip, salt glaze, grey stoneware (Fig. 4:13);

5 fragments from the vessels imitating products of Falke-Group, from four or three vessels, including: 1 fragment of belly of cylindrical beaker decorated on entire surface with single stamps in form of the cross; exterior covered with green glaze; light-yellow stoneware (kaolin clay; Fig. 4:14); 2 fragments of cylindrical beaker decorated on entire surface with rhomboid stamp with concentric smaller rhombuses in the interior; exterior covered with orange slip; red earthenware (Fig. 4:15-16); 1 fragment of cylindrical beaker, perhaps from above mentioned vessel, decorated on entire surface with rhomboid stamps with concentric, smaller rhombuses in the interior; exterior covered with orange slip, red earthenware (Fig. 4:17); 1 fragment of belly of uncertain vessel, decorated with single, square stamps with four dots in the interior; brown slip, salt glaze; red earthenware (Fig. 4:18).

Chronology: 15th-16th cent.

References: Kałagate 1994, 165-168, Fig. 4-5; Stephan 2004, 303-304, Fig. 15-16; Michalak 2021.

\section{Zielona Góra, Zielona Góra commune, Zielona Góra district}

I. Find place: site 18 (PAR 62-14/31), town (excavations in 1995), trench VIII B1, 15 wn; acc. no. 45/95.

Description: most likely fragment of the upper part of jug, decorated with fluted roller and diagonal band of double and single, square stamps with four dots in the interior; dark-brown slip and salt glaze; light-grey stoneware (Fig. 8:1 ).

Chronology: 15th-16th cent.

References: Stephan 2004, 324, Fig. 40:a.

II. Find place: site 18 (PAR 62-14/31), town, Old Market Square (excavations in 2008).

Description: 1 fragment of lower part of jug with separated base, decorated with single, square stamps with four dots in the interior, creating distorted system of hanging triangles; brown slip, salt glaze; grey stoneware (Fig. 8:2).

Chronology: 15th cent.

References: Lewczuk 2008. 

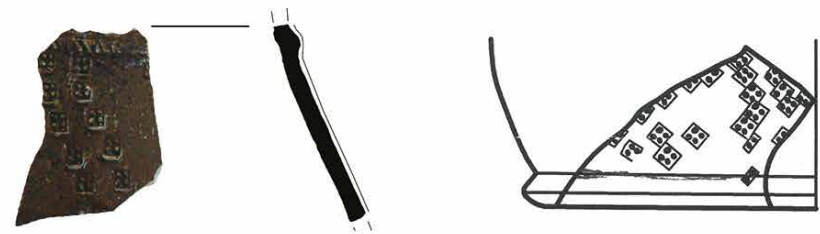

1
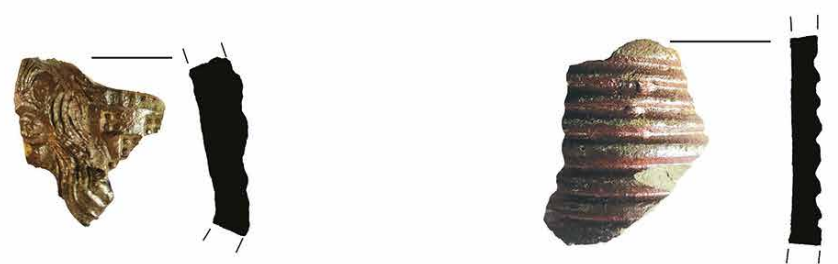

3

4

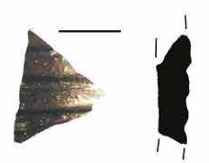

5
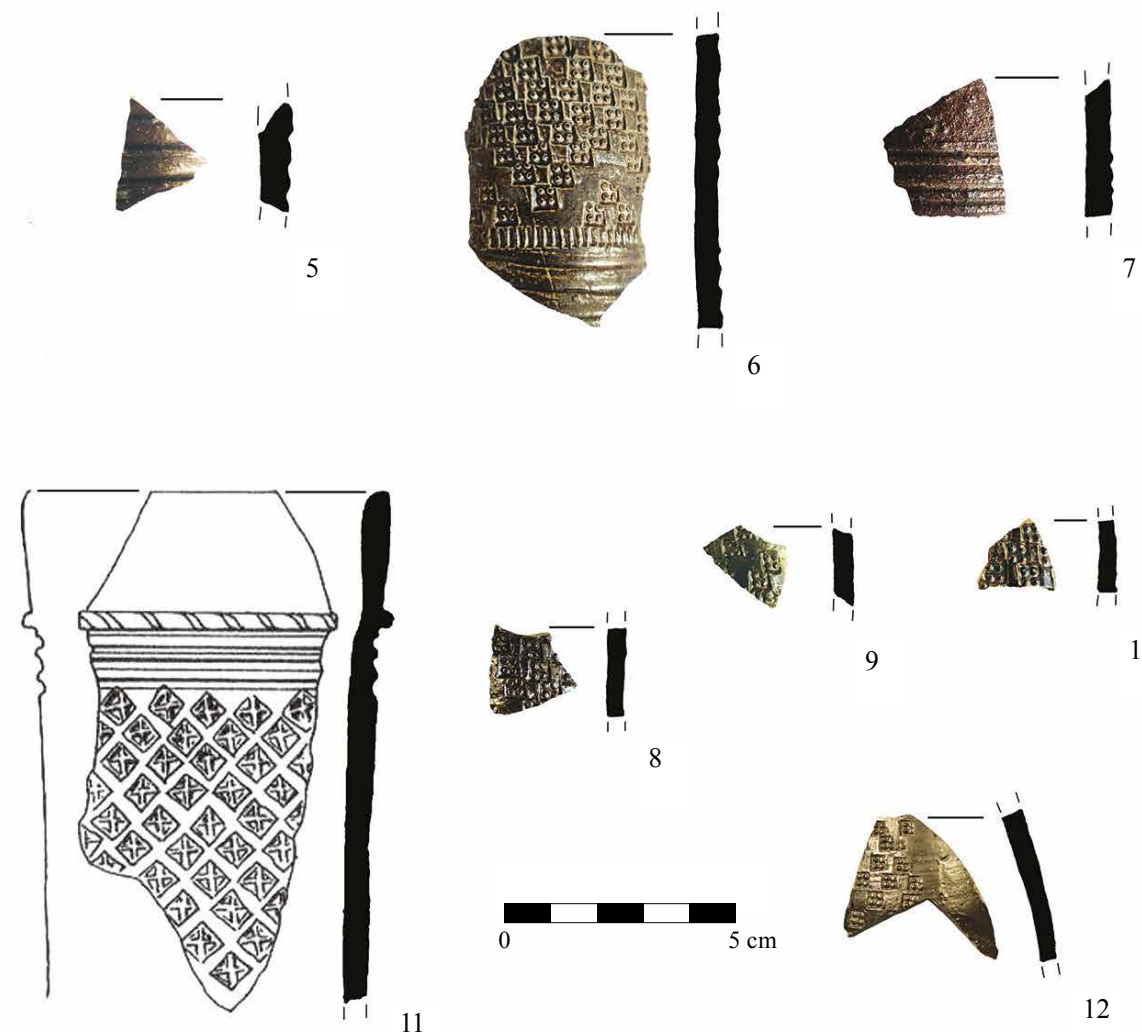

9

10

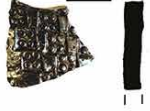

7

8

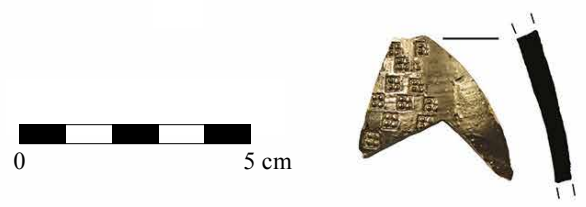

12

Fig. 8. Falke-group ceramics from analysed area. 1-2 - Zielona Góra (cat. 12); 3-10 - Żagań (cat. 13); 11-12 - Żary (cat. 14). 2 after Lewczuk 2008; $1,3-12$ drawing and photo by $S$. Kalagate.

Obr. 8. Keramika Falkeho skupiny z analyzované oblasti. 1-2 - Zielona Góra (kat. 12); 3-10 - Żagań (kat. 13); 11-12 - Żary (kat. 14). 2 podle Lewczuk 2008; 1, 3-12 kresba a foto $S$. Kalagate. 
III. Find place: site 18 (PAR 62-14/31), town, Powstańców Wielkopolskich Square (excavations in 2007).

Description: 1 fragment of upper part of body of cylindrical beaker, decorated with single, square stamps with four dots in the interior, without any clear arrangement; brown slip, salt glaze; grey stoneware.

Chronology: 15th-16th cent.

References: unpublished.

\section{3. Żagań, Żagań commune, Żagań district}

Find place: site 16 (PAR 69-12/10), monastery complex of the Augustinians (excavations in 2021), fraternity, cellar, test trench II, fill of the sump; acc. no. Zag ZA 2/21.

Description: 7 fragments from three-four vessels: 1 fragment of body sherd with facemask, in form of male head (?), decorated with square stamps with four dots in the interior, brown slip, salt glaze; olive-grey stoneware (Fig. 8:3); 1 fragment of lower part of cylindrical beaker, decorated in lower part with horizontal grooves, above horizontal band incised with using knurl in form of vertical oblongs separated by an X sign, above square stamps with four dots in the interior, creating system of large, opposite triangles; brown slip, salt glaze; light-grey stoneware (Fig. 8:6); 1 fragment of lower part of cylindrical beaker, decorated with horizontal grooves, brown slip, salt glaze; dark-grey stoneware, red-grey interior (Fig. 8:4); 1 fragment of lower part of cylindrical beaker (?), decorated with horizontal grooves, brown slip, salt glaze; light-grey stoneware (Fig. 8:5); 3 small fragments of bellies of uncertain vessel, decorated with square stamps, without any clear arrangement; brown slip, salt glaze; light-grey stoneware (Fig. 8:8-10); 1 fragment of lower part of cylindrical beaker, decorated with horizontal grooves; brown slip, salt glaze; light-grey stoneware with visible temper (Fig. 8:7).

Chronology: 15th-16th cent.

References: unpublished.

\section{4. Żary, Żary commune, Żary district}

Find place: site 4 (PAR 68-10/25), town, Osadników Wojskowych Street (excavations in 1999), trench $\mathrm{V}$, acc. no. 37/99.

Description: 2 fragments from different vessels: 1 fragment of upper part of cylindrical beaker, decorated on entire surface with single, square dots with cross in the interior, transition zone between belly and rim underlined with horizontal grooves and roller; dark-brown slip and salt glaze; grey stoneware (Fig. 8:11); 1 fragment of belly of jug decorated with square stamps with four dots in the interior, creating triangle (?) and wide semicircular groove; dark-brown slip, salt glaze; olive-grey stoneware (Fig. 8:12).

Chronology: 15th-16th cent.

References: Stephan 2004, 324, Fig. 40:b-c. 


\section{Bibliography}

ANSORGE, J., 2002: Frühe valenzianische Lüsterware und Steinzeug der Falke Gruppe aus dem Grauen Kloster in Greifswald, Archäologische Berichte aus Mecklenburg-Vorpommern 9, 240-262.

BARTHEL, H.-J., 1968: Das „Stiefelgefäß“ von Erfurt, Ausgrabungen und Funde 13/5, 275-278.

BERRY CH, J., 1994: The Idea of Luxury: A Conceptual and Historical Investigation. Cambridge.

BEUTMANN, J., 2002: Schnabelschuh auf Trippe. Ein ungewöhnliches spätmittelalterliches Gefäßfragment aus Zwickau, Arbeits- und Forschungsberichte zur sächsischen Bodendenkmalpflege 44, 401-404.

BŘICHÁČEK, P., 1997: Středověká kamenina Falkeho skupiny z hradu Landštejna, okr. Jindřichův Hradec. In: Život v archeologii středověku - Das Leben in der Archäologie des Mittelalters. Festschrift für Miroslav Richter und Zdeněk Smetánka (Kubková, J., ed.), 88-92. Praha.

DĄBAL, J., 2009: Nowe znaleziska naczyń kamionkowych grupy Falkego z Gdańska. In: Acta Archaeologica Pomoranica III. XVI Sesja Pomorzoznawcza 22.-24. 11. 2007 r. Szczecin. Część 2: Od późnego średniowiecza do czasów nowożytnych (Janowski A.-Kowalski, K.-Słowiński, S., edd.), 223-228. Szczecin.

DOLEŽEL, J., 1998: Dvě středověké, keramické imitace. K odrazu dálkových kontaktů v místní materiální kultuře středověké Moravy. In: Ve službách archeologie. Sborník k 60. narozeninám RNDr. Vladimíra Haška, DrSc. (Kouřil, P.-Nekuda, R.-Unger, J., edd.), 59-65. Brno.

DRNOVSKÝ, P., 2017: Nález zlomku kameninového poháru tzv. Falkeho skupiny na hradě Kumburku, okr. Semily, ASČ 21, 419-424.

DZIEDZIC, P., 2009: Nowe odkrycie fragmentu naczyń „grupy Falkego“ z Sulechowa- przyczynek do poznania bogato zdobionej kamionki gotyckiej, Lubuskie Materiały Konserwatorskie 6, 126-130.

- 2010: Relikty najstarszego zielonogórskiego wodociągu, Z Otchłani Wieków 65/1-4, 129-138.

DZIEDZIC, P.-KAŁAGATE, S., 2002: Badania archeologiczne na Zamku Piastowskim w Krośnie Odrzańskim (sezon 1998), Archeologia Środkowego Nadodrza 2, 65-186.

FALKE VON, O., 1907: Gotisches Steinzeug von Dreihausen in Hessen, Kunst und Kunstwerk 10, 295-309.

GABRIEL, F., 1987: České Švýcarsko očima archeologa. Děčín.

GAIMSTER, D., 1997: German Stoneware 1200-1900. Archaeology and Cultural History. London.

- 1999: The Baltic Ceramic Market c. 1200-1600: An Archaeology of the Hanse, Fennoscandia Archaeologica $16,59-69$.

GLINKOWSKA, B. et al., 2012: Glinkowska, B.-Krabath, S.-Bober-Tubaj, A.-Bojanowska, A.-Karpiński, M.-Olejniczak, A.-Orawiec, T.-Puk, A.-Szwed, R., U źródeł bolesławieckiej ceramiki. Bolesławiec jako jeden z ośrodków garncarstwa środkowoeuropejskiego od XV do XVII w. - Von den Anfängen der Bunzlauer Keramik - Funde des 15.-17. Jahrhunderts aus einem mitteleuropäischen Zentrum der Töpferei. Bolesławiec.

GLINKOWSKA, B.-ORAWIEC, T., 2016: Ceramika naczyniowa protokamionkowa i kamionkowa. In: Książęca wieża mieszkalna w Siedlęcinie w świetle badań archeologicznych (Nocuń, P., ed.), 206-229. Siedlęcin - Pękowice - Kraków.

GOŠ, V.-RYCHLÝ, M., 2016: Středověká kamenina na Jesenicku, VVM LXVIII, 324-328.

GWOŹDZIK, A., 2004: Międzyrzeckie naczynia typu „Dreihausen“ w świetle dotychczasowych badań nad kamionką gotycką. In: Ziemia międzyrzecka. Szkice z dziejów pogranicza (Tureczek, M.-Mykietów, B., edd.), 85-96. Międzyrzecz - Zielona Góra.

HASSE, M., 1979: Neues Hausgerät, neue Häuser, neue Kleider - Eine Betrachtung der städtischen Kultur im 13. und 14. Jahrhundert sowie ein Katalog der metallenen Hausgeräte, Zeitschrift für Archäologie des Mittelalters 7, 7-83.

HENKER, J., 2019: Dorfkernforschung in Klein Görigk. Keramik als Quelle zur historischen Entwicklung eines Niederlausitzer Dorfes. Wünsdorf.

HOLL, I., 1990: Ausländische Keramikfunde in Ungarn (14.-15. Jh.), Acta Archaeologica Academia Scientiarium Hungaricae 42, 209-266.

HORSCHIK, J., 1971. Beiträge zur Herkunftsfrage einer Gotischen Steinzeug-Gruppe und Aufführung ihres heutigen Bestandes, Keramos 53/54, 11-33.

- 1978: Steinzeug 15.-19. Jahrhundert. Von Bürgl bis Muskau. Dresden. 
KAŁAGATE, S., 1994: Ceramika z wieży rycerskiej w Witkowie, gm. Szprotawa, woj. zielonogórskie, stanowisko nr 6. In: Garncarstwo i kaflarstwo na ziemiach polskich od późnego średniowiecza do czasów współczesnych (Gruszczyńska, A.-Targońska, A., edd.), 161-184. Rzeszów.

- 2009: Fragmenty naczyń kamionkowych pochodzących z badań stanowiska Luboszów 2, gm. Osiecznica, woj. dolnośląskie. In: ... ad Oderam fluvium... Księga dedykowana pamięci Edwarda Dąbrowskiego (Gruszka, B., ed.), 387-397. Zielona Góra.

KAMIŃSKI, R. et al., 2009: Kamiński, R.-Słowiński, S.-Uciechowska-Gawron, A., Badania w otoczeniu pałacu w Kaliszu Pomorskim. In: Acta Archaeologica Pomoranica III. XVI Sesja Pomorzoznawcza 22.-24. 11. 2007 r. Szczecin. Część 2: Od późnego średniowiecza do czasów nowożytnych (Janowski, A.Kowalski, K.-Słowiński, S., edd.), 345-364. Szczecin.

KOWALSKI, S., 1987. Zabytki województwa lubuskiego. Zielona Góra.

KRABATH, S., 2012: Europejskie ośrodki produkcji kamionki we wczesnych czasach nowożytnych. In: U źródeł bolesławieckiej ceramiki. Bolesławiec jako jeden z ośrodków garncarstwa środkowoeuropejskiego od XV do XVII w. (Bober-Tubaj, A.-Dušek, L.-Glinkowska, B.-Kutschera, J.-Louda, J.-Orawiec, T.-Palata, O., edd.), 263-328. Jelenia Góra.

KOWALCZYK, A., 2012: Późnośredniowieczna i nowożytna ceramika kamionkowa z Poznania, Archaeologia Historica Polona 20, 191-218.

- 2014: Naczynia kamionkowe z Poznania w późnym średniowieczu i czasach nowożytnych. Poznań.

KURNATOWSKI, S., 2015: Charakterystyka stanowiska i prowadzonych tam badań. In: Międzyrzecz. Gród i zamek w wiekach IX-XIV. Wyniki prac wykopaliskowych z lat 1954-1961 (Kurnatowski, S., ed.), 19-62. Warszawa.

LEWCZUK, J., 2001: Perspektywy badań nad późnym średniowieczem i okresem wczesnonowożytnym w południowej części Środkowego Nadodrza, Silesia Antiqua 42, 149-176.

-2008: Wyniki ratowniczych badań archeologicznych przeprowadzonych w Zielonej Górze na terenie Starego Rynku w kwietniu i maju 2008 r., Zielona Góra. Typescript in the archive of LWKZ in Zielona Góra.

ŁASZKIEWICZ, T., 2003: Problematyka konserwatorstwa archeologicznego w działalności Muzeum w Międzyrzeczu w latach 1999-2000/2001. In: Archeologia Środkowego Nadodrza w ostatniej dekadzie XX wieku. Z badań pogranicza polsko-niemieckiego w aspekcie badań archeologiczno-konserwatorskich. Materiały z konferencji w Łagowie Lubuskim 12-13 września 2001 (Kałagate, S.-Jaszewska, A.Groblica, S., edd.), 182-191. Zielona Góra.

MACKIEWICZ, M., 2008: „Walka o miejsce na stole“- późnośredniowieczna ceramika luksusowa. In: Kultura materialna średniowiecza w Polsce (Kucypera, P.-Wadyl, S., edd.), 155-172. Toruń.

- 2012: Nowożytna ceramika artystyczna z badań archeologicznych przy kościele św. Piotra i Pawła na Ostrowie Tumskim we Wrocławiu. In: Nowożytny cmentarz przy kościele św. Piotra i Pawła na Ostrowie Tumskim we Wrocławiu (lata 1621-1670) (Pankiewicz, A., ed.), 129-160. Wrocław (Wratislavia Antiqua 17).

MAGDA-NAWROCKA, M., 1995: Mur obronny i fosa w Przewozie, Śląskie Sprawozdania Archeologiczne 36, 207-216.

MECHELK, H.W., 1970: Stadtkernforschung in Dresden. Berlin.

MICHALAK, A., 2010: Wieża rycerska rodziny von Warnsdorf w Witkowie, Z otchłani wieków 65/1-4, 167-173.

-2019: Arma Confinii. Przemiany późnośredniowiecznej broni na rubieżach Śląska, Wielkopolski, Brandenburgii i Łużyc. Zielona Góra.

- 2020: Moc apotropaionu. Nie tylko o starożytnych reminiscencjach w średniowiecznym uzbrojeniu z terenu ziem polskich, Gremium 14, 19-38.

- 2021: Wstępne sprawozdanie z badań zespołu zamkowego w Witkowie (sezon 2020). Zielona Góra. Typescript in the archive of LWKZ Zielona Góra.

MILLER, D., 1987: Material Culture and Mass Consumption. Oxford.

NAWROLSKA, G., 2011: Pucharek kamionkowy z „Grupy Falkego“ znaleziony na Starym Mieście w Elblągu, Elbląskie Studia Muzealne 2, 140-147.

NAWROLSKI, T., 1989: Średniowieczne naczynia kamionkowe typu Dreihausen, Kwartalnik Historii Kultury Materialnej 27/3-4, 467-512. 
NOWAKOWSKI, D., 2008: Siedziby książęce i rycerskie księstwa głogowskiego w średniowieczu. Wrocław.

PAWLAK, P., 2007: Ceramika naczyniowa. In. Żerniki, gm. Kórnik, stan. 25: osadnictwo pradziejowe, wieś średniowieczna i folwark nowożytny (Pawlak, E.-Pawlak, P., edd.), 61-162. Poznań.

PELA, W., 1997: A collection of decorated beakers from Pułtusk: a local invention or an attempt at imitation of imported stonewares? In: Imported and Locally Produced Pottery: Methods of Identification and Analysis (Buko, A., ed.), 111-123. Warszawa.

PIEKALSKI, J.-WACHOWSKI, K., 2013: „Rodzime i obce“ w krajobrazie kulturowym średniowiecznych ziem polskich, Archeologia Historica Polona 21, 127-167. https://doi.org/10.12775/AHP.2013.007

POBÓG-LENARTOWICZ, A., 1999: Kanonicy regularni na Śląsku. Życie konwentów w śląskich klasztorach kanoników regularnych w średniowieczu. Opole.

RODE, H., 1999: Eine stempelverzierte Keramikgruppe des frühen 15. Jahrhunderts. Untersuchungen zu Typologie, Herkunft, Verbreitung und Bedeutung der Falke Gruppe. Typescript of Masters thesis, Institut für Prähistorische Archäologie der Martin-Luther-Universität Halle-Wittenberg. Halle-Saale.

- 2000: Neue Untersuchungen zur Keramik der „Falke-Gruppe“. Ein Beitrag zur Erforschung der spätmittelalterlichen Steinzeugproduktion in Sachsen und der Oberlausitz, Keramos 169, 27-56.

- 2001: Die Keramik der Falke-Gruppe und ihre besondere Bedeutung für das Gebiet Ostsachens und der Lausitz, Neues Lausitziches Magazin 4, 7-22.

RUSSOW, E., 2014: Die Klöster in der Stadt Reval (Tallinn). In: Lübecker Kolloquium zur Stadtarchäologie im Hanseraum. IX: Klöster (Gläser, M., ed.), 531-543. Lübeck.

SCHWARZBERG, G., 2012: Von Luxus, Trunk und Propaganda - Spätmittelalterliche und frühneuzeitliche Figuralkeramik in Mitteleuropa. In: Masken der Vorzeit in Europa (II). Internationale Tagung Halle 19.-21. November 2010. Tagungen des Landesmuseums für Vorgeschichte Halle 7 (Meller, H.Maraszek, R., edd.), 129-142. Halle.

SCHWEDT, A. et al., 2003: Schwedt, A.-Mommsen, H.-Stephan, H.-G.-Gaimster, D., Neutron activation analyses of "Falke-group" stoneware, Archaeometry 45, 233-250. https://doi.org/10.1111/1475-4754.00106

SEDLÁČKOVÁ, L., 2018: Drobný střípek bohatě zdobené kameniny pozdní gotiky z Brna, BMD 31, $212-231$. SIKLÓSI, G., 1983: Dreihausener Pokal von Székesfehérvár, Alba Regia 20, 153-168.

SIKORA, M. et al., 2009: Sikora, M.-Wawrzyniak, P.-Augustyniak, H., Znalezisko dukata króla Macieja I Korwina w Kożuchowie, Lubuskie Materiały Konserwatorskie 6, 120-124.

SKIBIŃSKI, S., 1999: Jelenia Góra, ul. Grodzka, Silesia Antiqua 40, 211-212.

SŁOWIŃSKI, S., 2020: Naczynie ze szczecińskiego Podzamcza. Available from: http://encyklopedia.szczecin.pl/wiki/Naczynie_ze_szczeci\%C5\%84skiego_Podzamcza, cit. 6. 4. 2021.

STACHOWIAK, P., 2010: Wstępne sprawozdanie ze ścisłego nadzoru archeologicznego prowadzonego w związku z remontem zamku w Sulechowie, woj. lubuskie, Archeologia Środkowego Nadodrza VII, 263-267.

STARSKI, M., 2009: Późnośredniowieczne naczynia gliniane z zamku w Pucku. In: Studia i Materiały Instytutu Archeologii UW (Scholl, T.-Scholl, J., edd.), 195-284. Warszawa.

STEPHAN, H.-G., 2004: Badania nad ceramiką „grupy Falkego“. Bogato zdobiona gotycka kamionka łużycka i jej środowisko archeologiczno-historyczne. In: Wrocław na przełomie średniowiecza i czasów nowożytnych. Materialne przejawy życia codziennego. Wratislavia Antiqua 6 (Piekalski, J.-Wachowski, K., edd.), 293-329. Wrocław.

STEPHAN, H.-G.-GAIMSTER, D., 2002: Die „Falke-Gruppe“. Das reich verzierte Lausitzer Steinzeug der Gotik und sein archäologisch-historisches Umfeld, Zeitschrift für Archäologie des Mittelalters 30, $107-163$.

SZAJT, J., 2019: Naczynia grupy Falkego z Głogowa, Encyklopedia Ziemi Głogowskiej 79, $27-28$.

WACHOWSKI, K., 2013: Emblemata mediaevalia profana. Przykład Polski. Wrocław.

WAWRZYNIAK, P., 2012: Najnowsze badania miast w województwie lubuskim. Wybrane przykłady, Archaeologia Historica Polona 20, 131-160.

WOJCIECHOWSKA, I., 2017: Pierwsze znalezisko fragmentu naczynia kamionkowego „grupy Falkego” ze Stargardu, Materiały Zachodniopomorskie Nowa Seria XIII, 253-258. 


\section{Shrnutí}

\section{Zdání luxusu? Keramika Falkeho skupiny z pomezí Slezska, Lužice, Braniborska a Velkopolska}

Na pomezí Slezska, Velkopolska, Braniborska a Lužice, které se kryje s dnešními hranicemi Lubušského vojvodství, byla nalezena zajímavá kolekce kameninových nádob zdobených charakteristickým šachovnicovým vzorem, v odborné literatuře nazývané jako Falkeho skupina. Dosud bylo získáno přibližně 100 zlomků z několika lokalit na zkoumaném území, při pátrání v muzejních sbírkách se však podařilo identifikovat další desítky zlomků z různých druhů lokalit. Pouze jedenáct zlomků z této oblasti bylo podrobeno fyzikálně-chemické analýze, která potvrdila jejich prriřazení $\mathrm{k}$ Falkeho skupině; místo výroby zbývajících zlomků bylo určeno na základě formálních znaků a analogií. Cílem tohoto př́spěvku je představit kompletní kategorizaci nalezených zlomků a poukázat na prvky, které rozšiřují dosavadní interpretaci a kontext nálezů, a to nejen z polské, ale i evropské perspektivy.

Hlavní dekorativní motiv představují různá uspořádání malých čtvercových otisků kolku se čtyřmi tečkami. Otisky jsou sestaveny do několika vodorovných řad, velkých trojúhelníků nebo pokrývají celý povrch nádob. Na tomto typu nádob se vyskytují také motivy protilehlých trojúhelníků, tvořených malými vypouklými trojúhelníky, nebo pásy malých obdélníků posetých vroubky. Vyskytují se také pásy malých obdélníků s otiskem vroubků.

Ve většině př́ípadů jsou patky nádob zdobené řasením. Nádoby této skupiny jsou často zdobeny dekorativními maskami: obvykle vousatých mužů, méně často žen nebo mladíků. Charakteristickým znakem těchto nádob je šedavá barva, převážně v tmavém odstínu, přičemž vnější povrch je pokryt různými odstíny hnědých engob a solné glazury. Do této skupiny patří neobvyklé, zdánlivě emblematické tvary číšek (bota, pohár ve tvaru ježka) i válcovité a vakovité nádoby s nálevkovitým hrdlem, džbány apod. Na základě charakteristických výzdobných motivů O. Falke chybně určil jako místo výroby vesnici Dreihausen u Marburgu v Horním Hesensku. Tyto výrobky byly po dlouhá léta označovány jako keramika nebo kamenina typu Dreihausen. Nárůst nálezů ze Saska a Lužice přiměl badatele hledat místa jejich výroby nejprve v Sasku nebo Durynsku a později v lužických dílnách, snad v Budyšíně nebo Žitavě.

Většina zkoumaných keramických zlomků pochází z dokonale utvářených nádob. Všechny byly zhotoveny $z$ dobře připravené hlíny a tvarovány na rychle rotujícím hrnčířském kruhu. Nádoby byly ve většině případů kvalitně vypáleny. Ostřivo obsažené v keramickém těstě bylo roztaveno a pouze u několika zlomků byla zaznamenána přítomnost neroztavených zrn prríměsí. Barva těla je obvykle šedá nebo světle šedá, méně často šedá s olivovým odstínem, případně hnědošedá. Ve většině případů pocházejí analyzované zlomky z nádob, které byly pokryty hnědou či tmavě hnědou engobou nebo hnědou engobou s třešňovým odstínem a následně potaženy solnou glazurou.

Výsledky předběžné technologické analýzy ukazují, že shromážděný soubor není homogenní. Je velmi pravděpodobné, že analyzované fragmenty byly vyrobeny v různých keramických dílnách. Nelze vyloučit, že se zaznamenané rozdíly vyskytují i v rámci výrobků z jednoho hrnčíř ského výrobního centra, ale v současné fázi výzkumu podporují shromážděné argumenty spíše první tezi.

Mezi diskutovaným materiálem je zastoupeno několik tvarů nádob: válcovité poháry, hruškovité poháry, pokličky, džbány a nádoby neznámého (nerozpoznaného?) tvaru. S vysokou mírou pravděpodobnosti se zde vyskytují i zlomky, které lze považovat za součást protáhlých úzkých špic z pohárů v podobě špičaté boty (Trippenpokal). Ojedinělý je i zlomek neurčitého typu nádoby, který připomíná horní část láhve, tedy tvar dosud neznámý ve výrobcích Falkeho skupiny.

Nejtypičtějším vzorem, který se objevuje na keramice této skupiny z dané oblasti, je čtvercový nebo kosočtvercový otisk kolku se čtyřmi symetricky umístěnými tečkami uvnitř. Používal 
se také otisk ve tvaru konkávního čtyřúhelníku s vepsaným konvexním kř́ižem. Unikátní je ornament spojených čtverců vyplněných stř́idavě konvexními vodorovnými a svislými liniemi a otisk konkávního čtvercového pole protnutého vystouplými liniemi tvořícími kosočtverce, $\mathrm{s}$ jediným konvexním bodem. Ojedinělým nálezem je i fragment s kosočtvercovým otiskem s jediným vystouplým bodem uprostřed. Na několika málo zlomcích z analyzované oblasti je patrný ornament v podobě kruhových otisků s jedním konvexním bodem a řadou trojúhelníků. Nejzajímavějším výzdobným motivem objevujícím se na nádobách této skupiny jsou obličejové masky, které lze interpretovat jako apotropaické prvky chránící majitele před zlými silami. Jejich př́itomnost byla zaznamenána nejméně na čtyřech tvarech (z Kożuchowa, Międzyrzeczi, Witkowa a Żaganě); džbán z Kożuchowa byl zdoben dvěma kruhovými aplikacemi. Všechny se výrazně liší rysy obličeje, účesem a pokrývkou hlavy.

Rychlý rozvoj středních vrstev pozdně středověké společnosti v průběhu druhé poloviny 13. století a ve 14. století vedl $\mathrm{k}$ velké poptávce po dováženém zboží. Tyto tendence se také podepsaly na vzniku napodobenin luxusní kameniny Falkeho skupiny, vyráběných místními keramickými dílnami. Tyto napodobeniny byly nalezeny v Kożuchowě, Sulechowě, Witkowě a Krosnu Odrzańskiem. Tělo těchto nádob má cihlově červenou barvu a vnější stěnu pokrývá medová glazura. Po celém povrchu jsou nádoby zdobeny protilehlými trojúhelníkovými otisky kolků se třemi a čtyřmi tečkami uvnitř.

Kameninové nádoby Falkeho skupiny byly používány v různých společenských vrstvách. Analyzovaný materiál pochází převážně z lokalit obývaných prŕśslušníky tehdejších elit. Několik zlomků a napodobenin bylo nalezeno na hradech v Krosnu Odrzańskiem, Szprotawě, Sulechově a Międzyrzeczi. Uživateli nádob získaných na malých hradech ve Witkowě a Sękowicích byli pravděpodobně prríslušníci šlechtické elity z blízkého okruhu knížat ze Żaganě. Zvláštní pozornost je třeba věnovat fragmentům objeveným v oblasti Żaganě v areálu augustiniánského kláštera. Kontext nálezu nádob z analyzované oblasti naznačuje, že je používali bohatší měšt’ané (snad patriciát). Města, z nichž byly získány, však lze navzdory skutečnosti, že se jednalo o hlavní zemská města, jen stěží považovat za velká centra: Międzyrzecz, Zielona Góra, Kożuchów, Sulechów, Żary, Przewóz. Existují také fragmenty svědčící o použíání těchto nádob ve venkovském prostředí: Przewóz, Stare Czaple, Chełmica, Luboszów.

Výše uvedené příklady potvrzují příležitostné používání nádob Falkeho skupiny ve venkovském prostředí, což mohlo souviset $\mathrm{s}$ aspiracemi bohatších představitelů selského stavu přiblížit se životní úrovni vyšších společenských vrstev.

Analyzované zlomky pocházejí především z kontextů, které lze na základě doprovodného materiálu datovat do 15.-16. století. Je třeba zdůraznit, že kameninové tvary a jejich keramické imitace byly používány současně.

Sławomir Kalagate MA, Archaeological-Conservation Laboratory of Alina Jaszewska, Ceramiczna Street 2, 65-954 Zielona Góra, Poland, skvk@o2.pl

Arkadiusz Michalak PhD, The Archaeological Museum of the Mid-Odra River Area, Długa Street 27, 66-008 Świdnica, Poland, a.michalak@muzeum-swidnica.org 
